\title{
An Ethiopian Miniature of the Tempietto in the Metropolitan Museum of Art: Its Relatives and Symbolism
}

\begin{abstract}
This study offers the first comprehensive review of the Tempietto in Ethiopian art. The motif was an indispensable feature in illustrated Ethiopic Gospel books, appearing systematically as an explicit to the Eusebian apparatus in manuscripts from the Christian Aksumite to the early Solomonic Period. While the Ethiopic version of Eusebius's Letter to Carpianus and the canon tables have attracted considerable scholarly interest, the Ethiopian iconography of the Tempietto has not yet received the attention it deserves. By analysing the iconography of the Tempietto in Ethiopic gospel books this work shows how it is possible to offer a partial reconstruction of the practices of illuminators in Ethiopia in the century following the rise of the Solomonic dynasty, providing important insights into the elusive question of the development of manuscript illumination in Ethiopia.
\end{abstract}

\section{Introduction}

As far as the present evidence goes, the Tempietto was an indispensable feature in illustrated Ethiopic gospel books, appearing systematically as an explicit to the Eusebian apparatus in manuscripts from the Christian Aksumite to the early Solomonic Period. ${ }^{1}$ The Ethiopic version of Eusebius's Letter to Carpianus ${ }^{2}$ and the canon tables, ${ }^{3}$

I would like to thank Alessandro Bausi, Michael Gervers, and the Vatican Apostolic Library for allowing me to use their photographs. This study was made possible by the Beta mașāhoft project, a Getty/ACLS Fellowship in art history, and the Monumental Art of the Christian and Early Islamic East project (grant No 694105) led by the late Dr Judith McKenzie, to whose memory this study is dedicated.

1 For the boundaries of this period, see Heldman 1993b.

2 For a general overview of the Letter and the Eusebian Apparatus, see Oliver 1959; Crawford 2015. The text of the Letter to Carpianus and other prefatory texts found in Ethiopic gospels were first translated in English by Cowley 1977, but the only critical edition recently published is Bausi 2015. The Ethiopic version of the Letter to Carpianus ultimately derives, as do many other features of Ethiopic gospels, from a Greek Text, Zuurmond 1989, I, 19-20; Bausi 1997, 19-21.

3 For a general introduction to the canon tables, see Nordenfalk 1938, 1963, 1982, 1984; Vieillard 1945; Leroy 1957; Klemm 1972; McGurk typically placed in the intercolumniation of a single decorated arch and distributed over two or three and over eight or seven pages respectively, have attracted considerable scholarly interest. The Ethiopian iconography of the Tempietto, on the other hand, has not yet received the attention it deserves.

Nordenfalk simply notes that the Tempietto appears in Ethiopic gospels, without developing the point further, ${ }^{4}$ whereas Underwood's seminal study of the fons vitae deals tangentially with the Ethiopian tradition. ${ }^{5}$ A preliminary overview of the Ethiopian material offered over 50 years ago by Leroy ${ }^{6}$ has been followed by occasional remarks, ${ }^{7}$ reviewed below, rather than by systematic research. ${ }^{8}$ An exception to this statement is a meticulous study by Bausi which, however, focuses in detail on the textual rather than visual elements. ${ }^{9}$ Hence, the need for the review of the evidence presented here.

The focus of this paper is on a remarkable miniature of the Tempietto on the recto of a double-sided leaf from an Ethiopic gospel now kept in the Metropolitan Museum of Art (Fig. 1). ${ }^{10}$ Acquired in 2006, ${ }^{11}$ the leaf, which features a representation of the Crucifixion without the Crucified on its verso, ${ }^{12}$ offers one of the finest examples of this motif in early Solomonic manuscript illumination. This study seeks to explore its iconographic and stylis-

1993; D’Aiuto 2005; Amirkhanian 2008. For the Ethiopian version of the canon tables, see Leroy 1962; Zuurmond 1989, I, 20-21; Heldman 2003; Bausi 2004; Lepage/Mercier 2012, 102-107; McKenzie/Watson 2016; Gnisci/Zarzeczny 2017, 131-132; Gnisci 2018, 358-369. The canon tables in the Ethiopian tradition are called 'arches' ( $\left.h^{\prime}{ }^{a}{ }^{a} C\right)$,

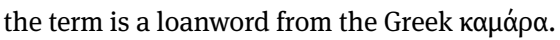

4 Nordenfalk 1938, 105.

5 Underwood 1950.

6 Leroy 1962.

7 Most recently, see the excellent study by Kessler 2016, esp. 29-33. 8 See Heldman 1972, 104-109, 1979a, 107; Leroy 1967, 23-24; Iacobini/ Perria 1998, n. 24. More extensive research on the motif on the Tempietto is found in McKenzie/Watson 2016, 121-44, but the focus is on the two Garima Gospels rather than on the later tradition considered here.

9 Bausi 2004, 53-56.

10 Acc. no. 2006.100.

11 Fletcher 2005, 80-81; Evans 2006.

12 The miniature of the Crucifixion is discussed in BalickaWitakowska 1997, 120-121. 


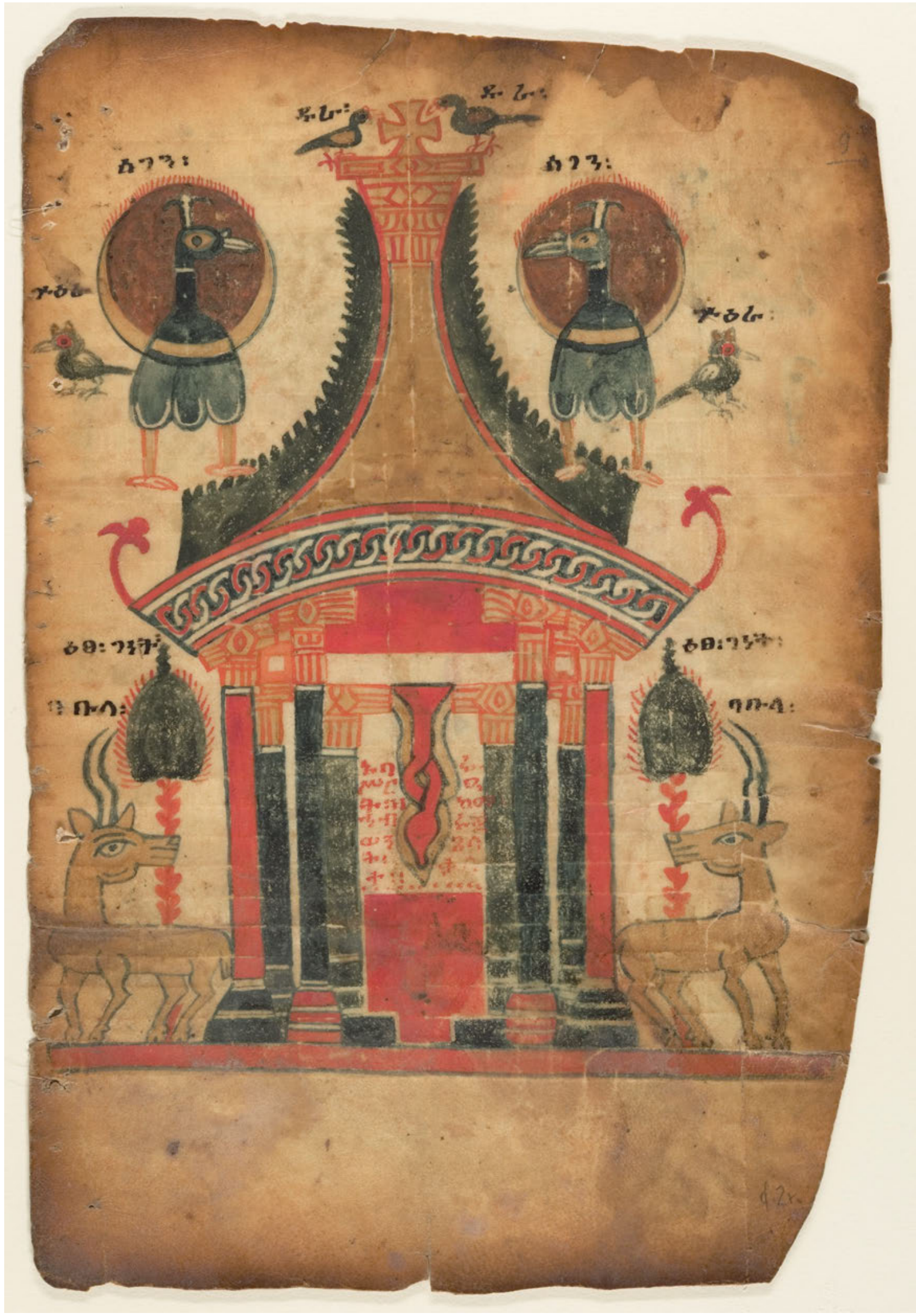

Fig. 1: Leaf from an Ethiopic gospel book, Tempietto, New York, The Metropolitan Museum of Art, acc. no. $2006.100,27.8 \times 19 \mathrm{~cm}$. @ The Metropolitan Museum of Art. 


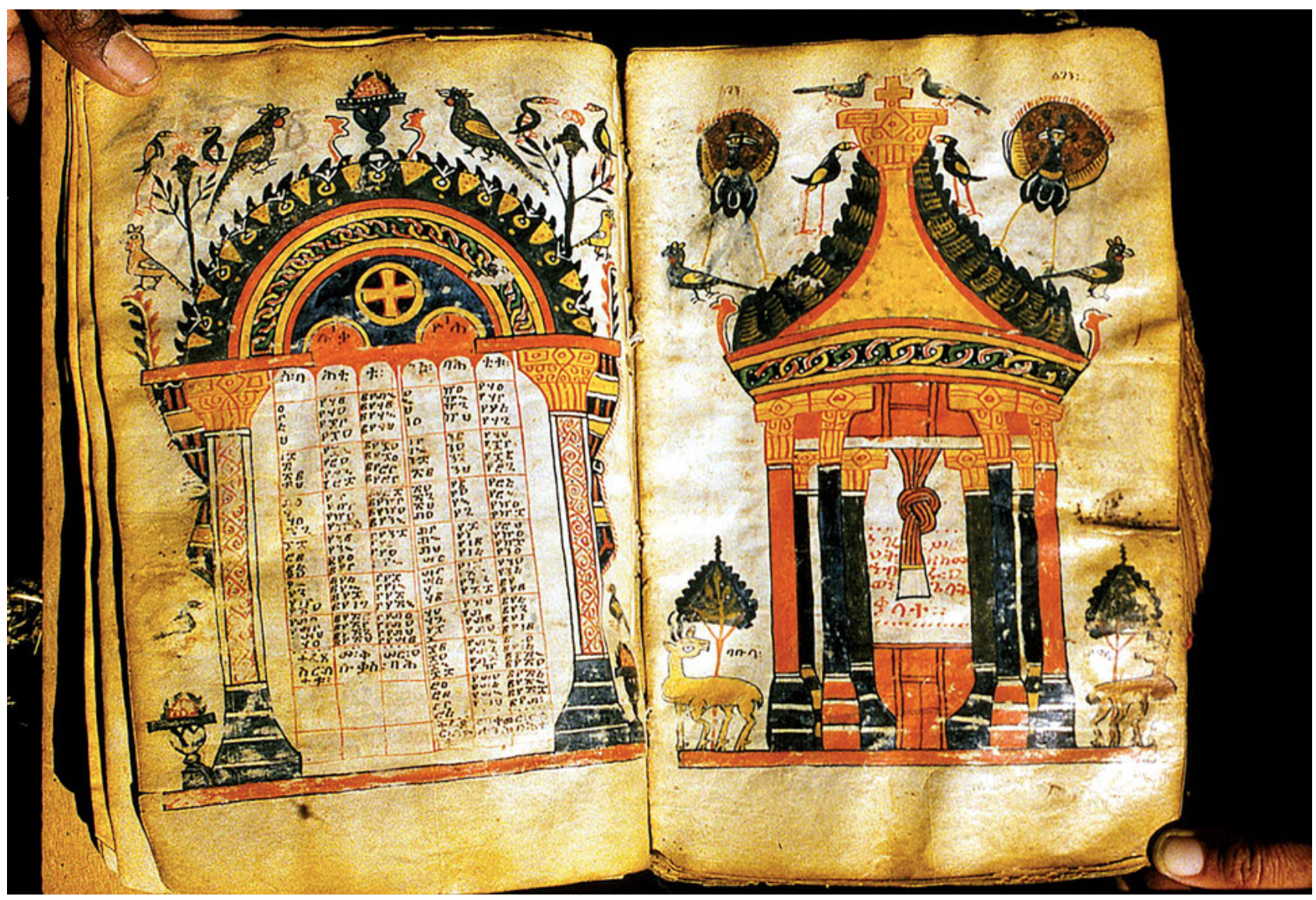

Fig. 2: Gospel book, Tempietto, Gär'alta, Däbrä Mä'ar, fol. 10r, 28.2 × $18.5 \mathrm{~cm}$. $\odot$ Michael Gervers, courtesy of the DEEDS project.

tic relationship to other roughly coeval witnesses of the subject in illustrated Ethiopic gospel books dating from the late thirteenth to the early fifteenth centuries.

In so doing, it presents, for the first time, a complete survey of the surviving witnesses of this motif. Furthermore, in centering on aspects of artistic interrelation, it shows how it is possible to offer a partial reconstruction of the artistic practices in Ethiopia in the century following the rise of the Solomonic dynasty. ${ }^{13}$ Finally, it demonstrates how an analysis of the motif of the Tempietto in the Ethiopian tradition yields important insights into the elusive question of the development of manuscript illumination in Ethiopia, for this is one of the few motifs attested in manuscripts predating the Solomonic Period, as illustrated in Table 1 (to which I refer for the sigla henceforth used).

13 For a general overview of this period, see Taddesse Tamrat 1972; Derat 2003.

\section{Date}

A larger and better-known part of the gospel book to which the Met's leaf originally belonged is now in the Nationalmuseum in Stockholm (= NMB-2034). ${ }^{14}$ A study of these fragments shows that the Met's Tempietto miniature originally followed the Eusebian Apparatus and preceded a cycle of three full-page miniatures which began with the representation of the Crucifixion without the Crucified on its verso and continued with the depictions of the Holy Women at the Tomb and the Ascension now in Stockholm. The multiple frontispiece formed by these three miniatures, often referred to as the short cycle, is attested in several fourteenth- and early fifteenth-century Ethiopic gospels and has been the object of several studies. ${ }^{15}$

14 Stockholm, Nationalmuseum, NMB 2034. The Stockholm fragment, which includes two pages of the Letter to Carpianus, two pages of canon tables, and Evangelist portraits, is mentioned in several studies, including Heldman 1979a, 1993b, 131-32; Nordenfalk 1979, 16-21. 15 The seminal studies for the Ethiopian tradition are those by Monneret de Villard 1939; Heldman 1979a; Lepage 1987, 1988, 1990; Fiaccadori 2003. On the motif of the Visit of the Holy Women at the 
Several decades before the Met's leaf appeared on the market, Heldman had associated the two miniatures from the Stockholm fragment with the multiple frontispiece of the Gospel of Däbrä Mä'ar (= DMR), ${ }^{16}$ which is likewise preceded by the Eusebian apparatus and the Tempietto (Fig. 2), and to a fragment kept in the Institute of Ethiopian Studies (= IES-3475), ${ }^{17}$ featuring the Tempietto on its recto and the Crucifixion without the Crucified on its verso. Thus, like the Met leaf, the Tempietto pages in DMR and IES-3475 have a crucifixion on the verso.

Until recently, the dating of these three manuscripts was tentative and based on stylistic, palaeographic, and iconographic considerations, with opinions on the matter varying from one author to another. Lepage initially argued, on stylistic grounds, that the illustrations in DMR belonged to the thirteen th or fourteenth century,${ }^{18}$ but later attributed them to the fourteenth century by dint of a note in the manuscript mentioning Säyfä Ar'ad (r. 1344-71). ${ }^{19}$ Balicka-Witakowska tentatively dated DMR to $c .1350,{ }^{20}$ NMB-2034 to the first half of the fourteenth century, ${ }^{21}$ and IES-3475 to $c .1375 .{ }^{22}$ Fiaccadori, in turn, attributed NMB2034 and IES-3475 to the fourteenth century, but dated DMR to 1341/42 in the light of a note mentioning Emperor 'Amdä Șəyon I (r. 1314-44). ${ }^{23}$ Finally, Heldman-who had previously suggested that DMR, IES-3475, and NMB-2034 belonged to the first half of the fourteenth century ${ }^{24}$-and Devens, who studied and translated a donation note in DMR (fols 230v-231r), confirmed the manuscript to have been donated to its monastery in $1340 / 41 .^{25}$

In the light of this new evidence, Heldman argued that the dating of IES-3475, NMB-2034 and the Met's leaf must be reconsidered because these fragments 'appear stylistically to be later in date than the miniatures of the

Tomb, see also Ernst 2009; Gnisci 2015a. For the Ascension, see Monneret de Villard 1943; Chojnacki 1976.

16 Heldman 1979a, 1993b, 131, was the first to point out the similarities between DMR and the Stockholm fragment.

17 For a reproduction and discussion of the Tempietto in this manuscript, see Heldman 1993b, 130-131, cat. 55; Balicka-Witakowska 1997,127 . This fragment is iconographically related to BNF-32, but is not stylistically close as suggested by Chojnacki 1983, 34, 490.

18 Lepage 1972, 500.

19 Lepage 1977b, 1977a, 1987.

20 Balicka-Witakowska 1997, 6, 126.

21 Balicka-Witakowska 1997, 125, n. 8.

22 Balicka-Witakowska 1997, 7.

23 Fiaccadori 2003, 200-201.

24 Heldman 1979a, 107-108.

25 Heldman/Devens 2009; Devens is acknowledged as 'responsible for the translation of the colophon and donation note' at the beginning of the study, so the art historical considerations in this study are attributed only to Heldman here.
Gospels of Däbrä Mä'ar'. ${ }^{26}$ Such a statement warrants some scrutiny. On the one hand, the short cycle formed by the Crucifixion on the verso of the Met's leaf and the miniatures of the Holy Women at the Tomb and the Ascension in NMB-2034 is indeed very close, in terms of style and iconography, to the frontispiece of DMR. Their iconographic features appear in much the same way in this latter manuscript, even though, as pointed out by several scholars, the illustrations in DMR appear to be more skillfully executed or, as Balicka-Witakowska puts it, 'closer to the presumed archetype'. ${ }^{27}$ On the other hand, it does not necessarily follow, as Heldman would have it, that the Met's leaf and NMB-2034 are posterior to DMR because they preserve fewer features of the presumed archetype. In fact, at the present state of our knowledge, it cannot be ruled out that their miniatures are almost coeval with those in DMR or earlier even, though the latter appears less likely. In other words, at present, it is safest to assert that the illustrations in NMB-2034 and on the Met's leaf are from the fourteenth century. However, if one were to narrow this date range on stylistic grounds alone, it may be argued tentatively they originated in the decades around the mid-fourteenth century. ${ }^{28}$

\section{Overview}

The principal features of the Tempietto miniature on the Metropolitan Museum's folio are typical of early Solomonic representations of this subject. A tholos is placed at the centre of the composition, occupying roughly three quarters of the height of the folio. The building's cornice is decorated with interlace and rests on eight columns with white astragals and narrow shafts in black, crimson red, and green. The columns have T-shaped capitals and barred bell-shaped bases. A knotted curtain dangles from the innermost part of the building. The conical roof, with trefoil-shaped acroteria, has concave sides which-like the lines of the cornice-were probably drawn with a compass. ${ }^{29}$ There is a vase-shaped capital topped by a small cross above the roof. There are also several animals, identified by captions and considered in greater detail below, placed around the tholos.

26 Heldman/Devens 2009, 82.

27 Balicka-Witakowska 1997, 121

28 The only analysis of the issues that arise in dating early Solomonic miniatures is found in Balicka-Witakowska 1997, 6-9, but the matter requires more detailed treatment than hitherto received.

29 Signs of a compass needle are visible at the centre of the circular tails of the two peacocks placed at each side of the roof. 


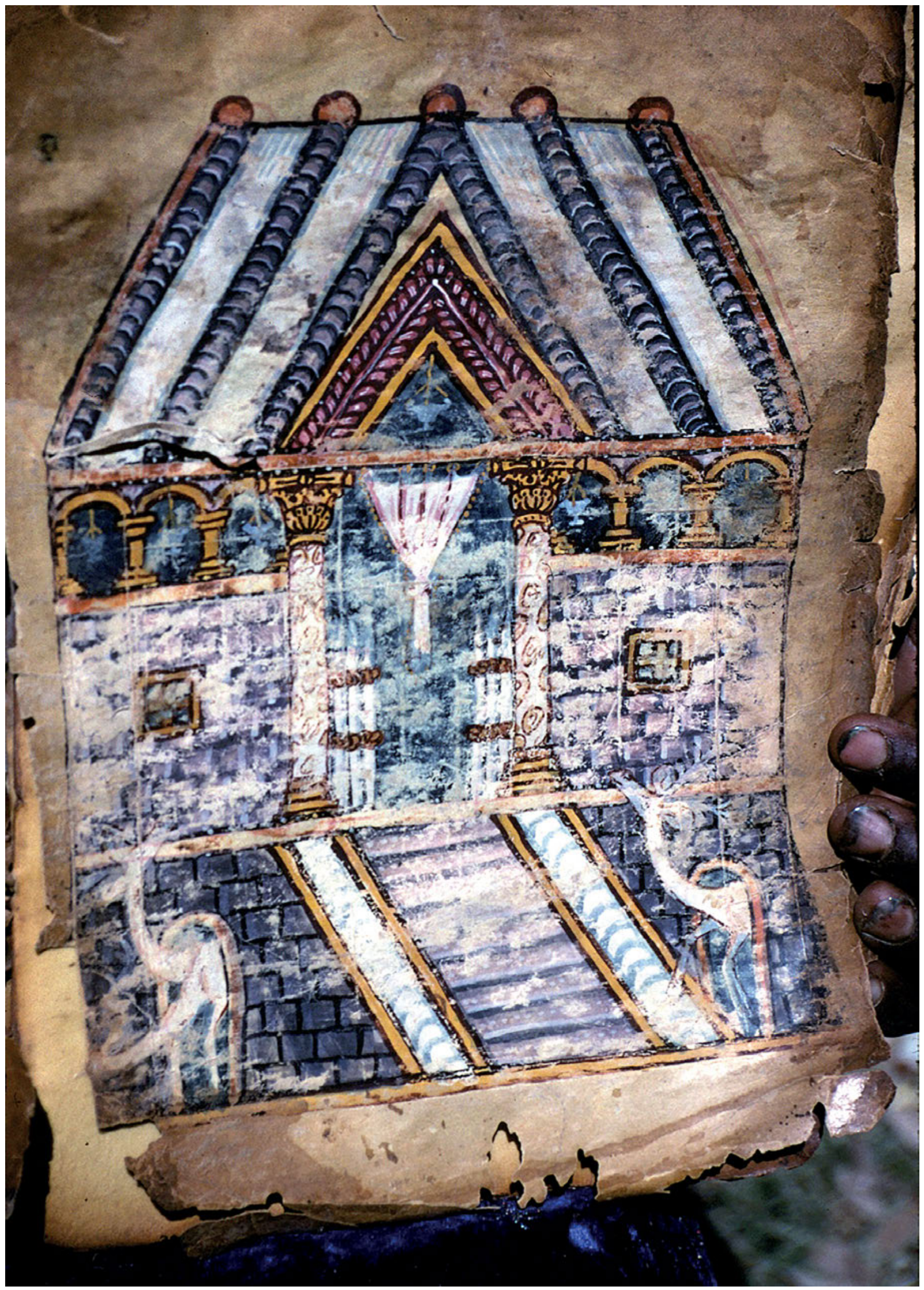

Fig. 3: Gospel book, Tempietto, 'Adwa, Inda Abba Garima, III, fol. 5v, $33.2 \times 25.4 \mathrm{~cm}$. ( $)$ Michael Gervers, courtesy of the DEEDS project. 
Tab. 1: The Tempietto in Ethiopic Gospel Books.

\begin{tabular}{|c|c|c|c|}
\hline Date & Repository \& Identifier & Folio & Abbreviation \\
\hline Fourth-seventh cent. (?) & 'Adwa, Jnda Abba Garima, III (Fig. 3)30 & $5 \mathrm{v}$ & AG-III \\
\hline Sixth-seventh cent. (?) & 'Adwa, Jnda Abba Garima, I (Fig. 4) ${ }^{31}$ & $6 r$ & AG-I \\
\hline Twelfth-thirteenth cent. (?) & Akkälä Guzay, Däbrä Libanos ${ }^{32}$ (Fig. 5) & $7 r$ & DLB \\
\hline $1280-81$ & Ḥayq, Däbrä Ḥayq ヨsțifanos ${ }^{33}$ (Fig. 6) & $12 r$ & IMA \\
\hline $1340-41$ & Gär'alta, Däbrä Mä'ar (Fig. 2) & $10 \mathrm{r}$ & DMR \\
\hline c. $1300-1339 / 40$ & Addis Ababa, National Library, MS $28^{34}$ (Fig. 7) & $14 \mathrm{r}$ & KTN \\
\hline Mid- to late fourteenth cent. (?) & Baltimore, The Walters Art Museum, W.836 35 (Fig. 8) & $6 r$ & WAM-836 \\
\hline Mid- to late fourteenth cent. (?) & New York, The Metropolitan Museum of Art, acc. no. 2006.100 (Fig. 1) & $\mathrm{n} / \mathrm{a}$ & \\
\hline Second half of fourteenth cent. (?) & Addis Ababa, The Institute of Ethiopian Studies, 3475a-b & $\mathrm{n} / \mathrm{a}$ & IES-3475 \\
\hline Second half of fourteenth cent. (?) & Șəra', Däbrä Șärabi³6 (Fig. 9) & $10 \mathrm{r}$ & DSB \\
\hline $1360-61$ & Säraye, Däbrä Maryam Qwäḥayn ${ }^{37}$ & $?$ & DMQ \\
\hline $1362-63$ or $1438-39$ & Amba Dära, Maryam Mägdälawit ${ }^{38}$ (Fig. 10) & $18 r$ & MMG \\
\hline c.1344-1412 & Lake Țana, Kəbran, Kəbran Gäbrə’el ${ }^{39}$ & $9 r$ & KGL \\
\hline Mid-fourteenth to early fifteenth cent. (?) & Gulo Mäk̋äda, 'Ura Mäsqäl ${ }^{40}$ & $6 r$ & UML \\
\hline Mid-fourteenth to early fifteenth cent. (?) & Paris, Bibliothèque nationale de France, éth. $32^{41}$ & $7 r$ & BNF-32 \\
\hline Mid-fourteenth to early fifteenth cent. (?) & Lake Ṭana, Däq, Arsima Säma'ətat ${ }^{42}$ & $?$ & AST \\
\hline Mid-fourteenth to early fifteenth cent. (?) & Täkwəlädäre, Boru Meda Abärra Śəllase ${ }^{43}$ & $8 r$ & BSS \\
\hline $1400-01$ & New York, The Morgan Library \& Museum, M. $828^{44}$ & $6 r$ & ZGL \\
\hline Early fifteenth cent. (?) & Däqqi Dašəm, Qəddus Mika’el, (non vidi) ${ }^{45}$ & $4 \mathrm{r}$ & DDM \\
\hline Early fifteenth cent. (?) & New York, The Metropolitan Museum of Art, acc. no. $1998.66^{46}$ & $16 r$ & MET-1998.66 \\
\hline Early fifteenth cent. (?) & Private Collection ${ }^{47}$ & $8 r$ & $P C-3$ \\
\hline
\end{tabular}

30 The dating of AG-I and AG-III is based on C-14 tests and analysis of the style of the miniatures. For a discussion and reproductions of these two manuscripts, see Leroy 1960, 1968; Heldman 1993b, 12930; Mercier 2000a, 36-45; Zuurmond/Niccum 2012; McKenzie/Watson 2016; Getatchew Haile 2017.

31 Despite a recent rebinding, some pages of AG-I are still not in the correct order, as noted also in McKenzie/Watson 2016. On the restoration of AG-I and AG-III, see Mercier 2009, 107-14. The verso of the Tempietto leaf features an empty canon table with a conch-shell that was probably originally placed before the tholos rather than after it. It is tempting to ask whether this page was intended as an allusion to the pronaos of the aedicule of the Holy Sepulchre, as preserved in the stone model of Narbonne. For reproductions and a more detailed discussion of this latter work, see Ousterhout 1990, fig. 8; Iacobini/ Perria 1998, 60; Fiaccadori 2003, 185-186.

32 This gospel book, kept in a homonymous monastery in Eritrea, is currently inaccessible due to the political situation. The manuscript contains codicological units from different periods, for a discussion see Conti Rossini 1901; Bausi 1997, 13-23, fig. 1, 2007b; Derat 2010, 24-34. 33 This manuscript, generally referred to by the name of its owner, Iyäsus Mo'a, is dated on the basis of a colophon on fol. 23v, see Taddesse Tamrat 1970, 90-92; Getatchew Haile/Macomber 1981, 293-301; Zuurmond 1989, II, 55-56; Balicka-Witakowska 1997, 123-24; BoscTiessé 2010; Gnisci 2015c.

34 Opinions on the dating of this manuscript vary, but the presence of historical notices and a portrait of its owner, Krəstos Täsfanä, provide an ad quem date of 1339/40, see Șādwā 1952; Ricci 1961, 97, pl. 20; Schneider 1970; Lepage 1977b, 336-342, 2002; Zuurmond 1989, II, 62-63; Heldman 1993a, 176-177, cat. 65; Chojnacki 1993; Gnisci/ Zarzeczny 2017, n. 98; Balicka-Witakowska 1997, 124-125. For a discus- sion and reproduction of the Tempietto, see Leroy 1962, 174-176, fig. 2. 35 The dating is based on stylistic and palaeographic considerations. There is no evidence supporting the statement that this gospel 'belongs to a group of manuscripts produced at a monastery in Northern Ethiopia' as argued by Mann 2001, 96. On this manuscript, see also Heldman/Devens 2009, 81; Gnisci 2015a, 568.

36 The dating is tentative and based on stylistic and iconographic evidence. The manuscript has not been the object of systematic research, for some preliminary observations, see Gervers 2013, 56; Gnisci 2015a, 568. For a reproduction and discussion of the Tempietto, see McKenzie/Watson 2016, 140, fig. 127.

37 The folios of this manuscript are in disorder. The dating is based on a colophon, which mentions Emperor Säyfä Ar'ad (r. 1344-71), see Bausi 1994, 24-44, who also discusses its content in detail. For a reproduction of the Tempietto and further remarks, see Leroy 1962, 187-190, fig. 12; see also Buxton 1970, 187-188; Balicka-Witakowska 1997, 127-128.

38 The manuscript, discovered by the Oxford University Expedition in 1974, can be dated on the basis of a colophon on fol. 206r, translated in Juel-Jensen/Rowell 1975, 73-83. Depending on whether the years are numbered from the Era of Martyrs or Creation the possible dates are $1362 / 63$ or 1438/39. The former option has more consensus among scholars, see Bausi 1994, n. 39; Balicka-Witakowska 1997, 130-131, with further bibliography. The miniature of the tempietto is unpublished.

39 Opinions on the dating of this manuscript vary in the literature, as it contains a number of notes of historical interest. In particular, there is disagreement whether to accept a note on fols $234 \mathrm{v}-235 \mathrm{r}$ which mentions Emperor Säyfä Ar'ad (r. 1344-71) or one on fol. 236v dated to 1412 which mentions Emperor Dawit II (r. 1379/80-1413) as 
The above elements appear-though some details were at times distorted by involuntary errors-in most miniatures of the Tempietto in early Solomonic gospels. The remarkable uniformity between these miniatures justifies the detailed description of their features that follows in this study. Even if the utility of 'collations' for art historical purposes has been questioned for other contexts, ${ }^{48}$ it is worth pursuing in the case of illuminated Ethiopic gospel books because the similarities and differences between their decoration have not been remarked upon so far and seem to me significant in at least three respects.

dating evidence for the manuscript. Stylistically, the work seems closer to the turn of the fifteenth century. For an overview, see Leroy/ Wright/Jäger 1961, 8-11, pls 7-21; Hammerschmidt 1973, 84-91; Taddesse Tamrat 1974, 506-507; Heldman 1979b; Davies 1987, 288; Uhlig 1988, 223; Heldman 1993a, 178-179, cat. 69; Balicka-Witakowska 1997, 9, 15, 37, 89-90; Bosc-Tiessé 2008, 33-39; Gnisci 2017. For a reproduction of the Tempietto, see Leroy/Wright/Jäger 1961, pl. 7.

40 The property of this church has been moved to the nearby compound of 'Ura Qirqos. The manuscript was recently digitized by the Ethio-SPaRe project (UM-027) and has yet to be the object of a detailed investigation. It contains several notes of historical interest, including one which mentions Emperor Säyfä Ar'ad (r. 1344-71) but is written in a hand which appears to belong to a much later period. Stylistically, it is close to works produced between the mid-fourteenth and early fifteenth centuries. For some preliminary remarks, see Nosnitsin 2013, 3-8; for a reproduction of the Tempietto, see Henze 2007, fig. 6.

41 The manuscript has been the object of numerous studies. It is sometimes dated on the basis of a donation note by Emperor Säyfä Ar'ad (r. 1344-71) on fol. 1v, but there is disagreement on whether this folio is a later addition. Stylistically and paleographically, it appears closer to the fifteenth century. For a more detailed discussion, see Grébaut 1931; Underwood 1950, 104-114 passim, fig. 53; Leroy 1962, 176-179; Heldman 1979a; Lepage 1987; Zuurmond 1989, II, 61-62; Uhlig 1988, 190-194; Iacobini/Perria 1998, n. 24; Gnisci 2015a; Velmans 2017, 72-75.

42 The dating is based on stylistic and iconographic considerations, since the unbound leaves from a gospel have been inserted in a manuscript of the Pauline Epistles. For a discussion and reproduction of the Tempietto, see Leroy 1962, 190, fig. 13. For further remarks on the miniatures, see Leroy/Wright/Jäger 1961, 11-12, pls 23-27; Chojnacki 1976, 165-166; Balicka-Witakowska 1997, 131-132; Gnisci 2015b.

43 The dating is based on stylistic and palaeographic evidence. For an overview of its features, see Getatchew Haile 1993, 298-299; Balicka-Witakowska1997,128-129. For its styleand iconography, Gnisci 2018, 370-382.

44 The dating is based on a colophon. On this manuscript, see Monneret de Villard 1939; Underwood 1950, 109-111; Skehan 1954; Leroy 1962, 172-182, fig. 6; Heldman 1972; Zuurmond 1989, I, 63-65.

45 The miniature of the Tempietto is mentioned in BalickaWitakowska 1997, 129.

46 The dating of this manuscript is based on stylistic and palaeographic evidence. For an overview of its features and a reproduction of the Tempietto miniature, see Lepage/Mercier 2012.

47 The miniature is published in Mercier 2000b, 54.

48 For instance, see Lowden 2002, 69.
Firstly, they reveal that most early Solomonic examples of the Tempietto discussed here derive from common sources. ${ }^{49}$ Secondly, they prove beyond question that their makers followed models when decorating gospel books. And thirdly, since they all present some degree of variation, they further our understanding of their makers' attitude towards copying and innovation. In other words, by studying miniatures of the Tempietto in Ethiopic gospel books we can start outlining a theory about the transmission of 'visual knowledge' in early Solomonic Ethiopia.

To this end, Table 1 provides a list of all known examples of the Tempietto in Ethiopic gospel books from the Aksumite period to the early fifteenth century along with relevant bibliographic information. Abbreviations are used to designate the various manuscripts and to make the text more concise.

\section{Architectural features}

The jagged pattern which covers the roof of the Tempietto in the Metropolitan leaf occurs, in varying degrees of stylization, in all the Ethiopian examples of the Tempietto listed in Table A except BNF-32, DMQ and BSS. Its absence in BNF-32 could be due to a simplification of forms rather than dependence on a different model. The question for DMQ and BSS is more complex and is discussed below. Comparison with the two earlier Ethiopian examples of this subject found in AG-I and DLB (Figs 4-5) 50 $^{50}$ indicates that the pattern represents plant growths.

In some Ethiopic gospels from the thirteenth and fourteenth centuries, such as IMA (Fig. 6), UML and DMR (Fig. 2), the growths are still discernible. In others, especially in the later examples, the vegetation is reduced to a sequence of triangles, as evident in MMG (Fig. 10), AST and ZGL. ${ }^{51}$

49 For the study of models in manuscript illustration, see the wellknown study by Weitzmann 1947, 182-192; on the limitations of his type of approach and the need to avoid a priori assumptions on the practices of illuminators, see Guilmain 1965; Lowden 1992, 35-104, esp. 79-80, 2002, 2007; Dolezal 1996, 1998, but not all these observations apply to illuminated Ethiopic manuscripts. For a recent overview of the philological approach to the study of manuscript illumination, see Bernabò 2017a, with further bibliography.

50 The similarities between the version of the Tempietto found in these two gospels have already been noted by Bausi 1997, n. 12. At the time of the study, the pages of the Gärima Gospels were mixed between the two manuscripts, so the author refers to the miniature as being in AG-III instead of AG-I.

51 A similar conclusion is reached, in discussing a Tempietto found in a fifteenth-century Ethiopic gospel book belonging to the church of Betä Maryam at Lalibäla by Lepage/Mercier 2012b, 286, fig. 10.6. 


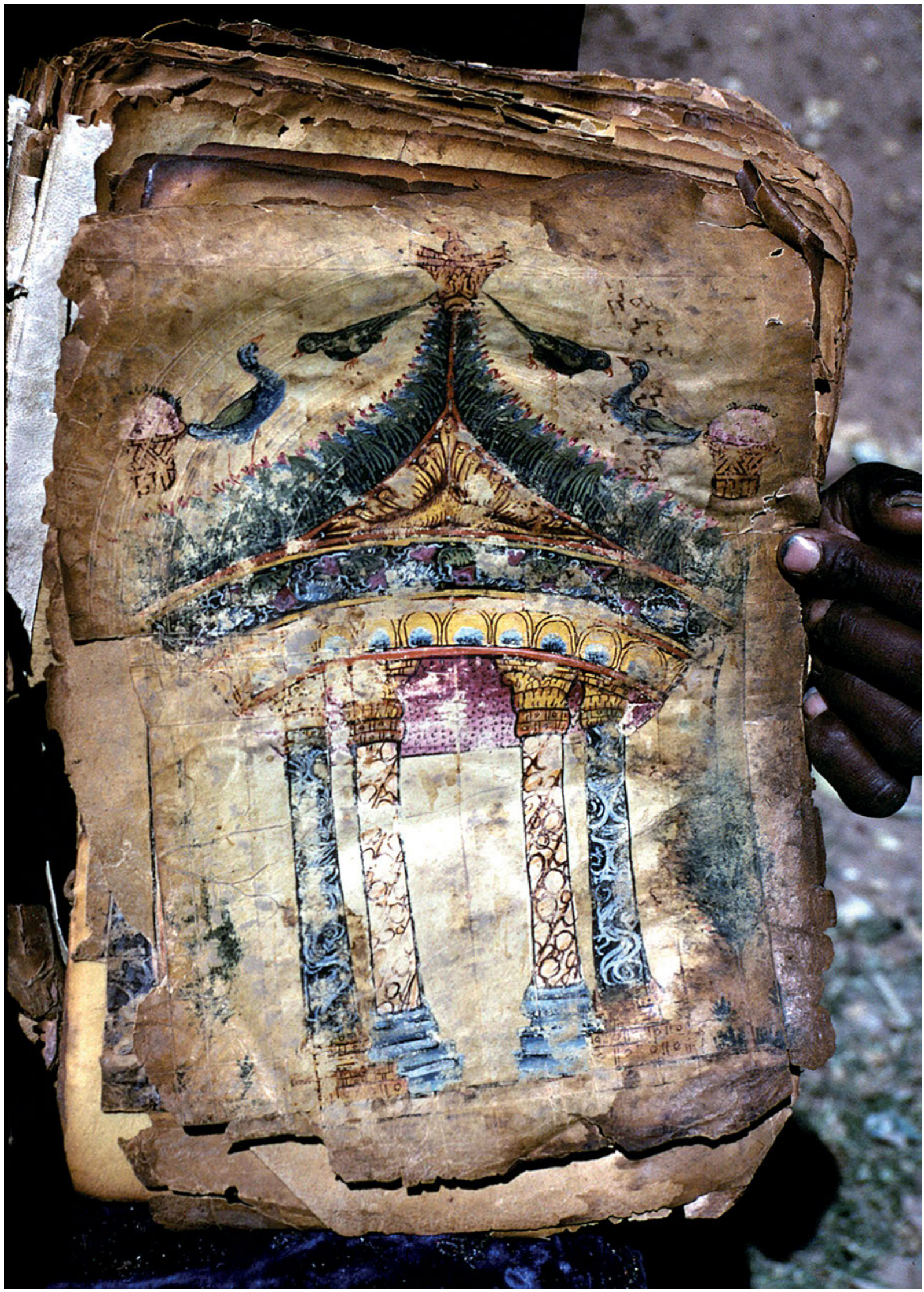

Fig. 4: Gospel book, Tempietto, 'Adwa, Jnda Abba Garima, I, fols 5v-6r, $35.3 \times 26.4 \mathrm{~cm}$. @ Michael Gervers, courtesy of the DEEDS project. 


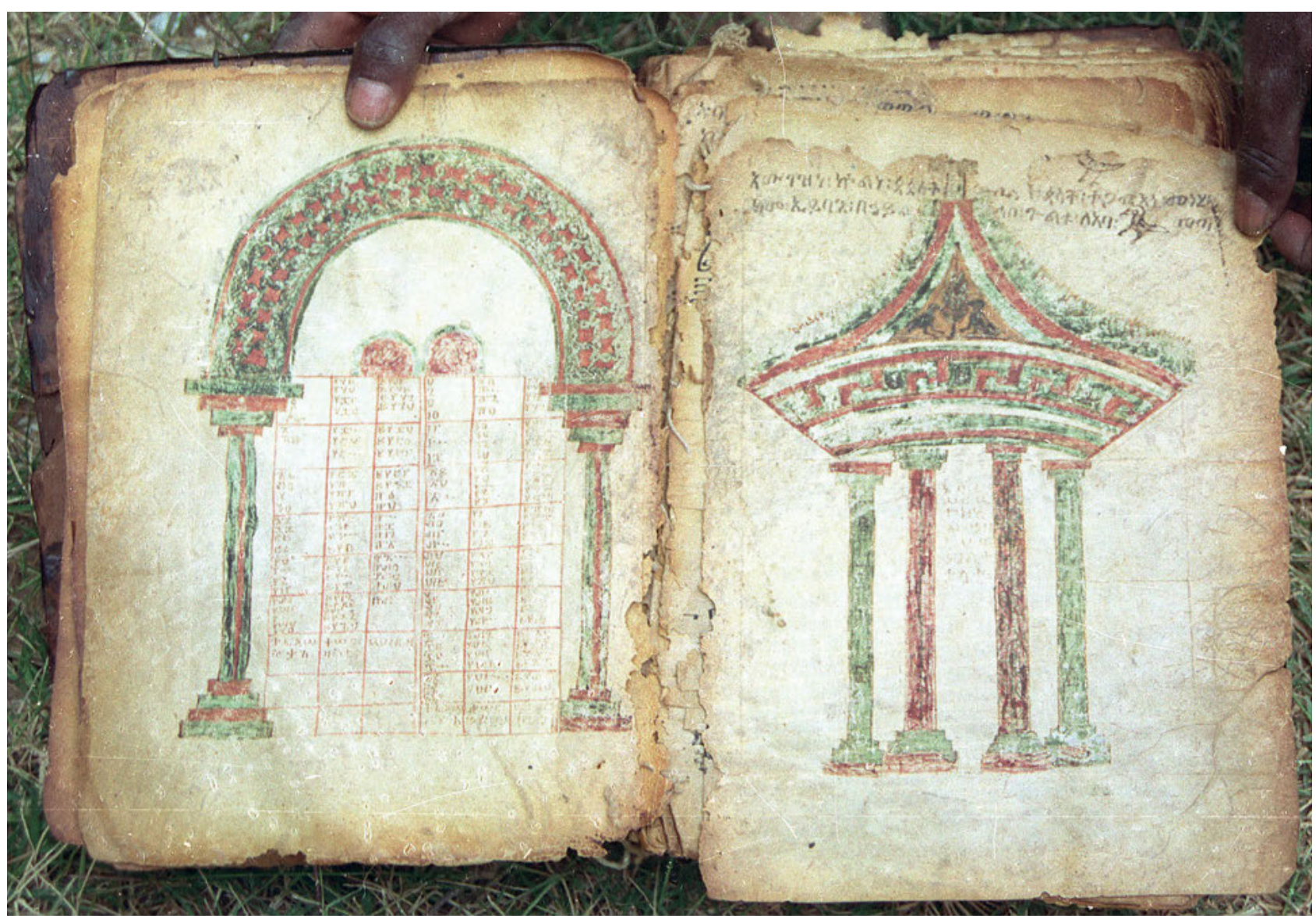

Fig. 5: Gospel book, Tempietto, Akkälä Guzay, Däbrä Libanos, fol. 7r. @ Alessandro Bausi.

The patterns that crest the roof of the Met's leaf, IES-3475, KTN and WAM-836 (Figs 1, 7-8) represent an intermediary stage in this shift towards greater abstraction. In KGL and MET-1998.66, where lozenge patterns replace the pointed elements, the stylization process has reached its culmination. Here all memory of the original feature seems lost and we can only reconstruct a convincing sequence of transmission by comparison with the earlier examples.

Elsewhere, I have shown that the artist of KGL was willing to amend, improve, and even mix his models when copying them..$^{52}$ He may well have been the first to introduce an elegant sequence of lozenge patterns in his representation of the Tempietto because he was unable to discern the significance of the vegetation above the building, though this cannot be proven beyond doubt. Certainly, miniatures featuring a lozenge pattern rather than plant growths above the roof of the Tempietto circulated and were copied during the fifteenth century, since the pattern is found also in MET-1998.66 and in later examples. ${ }^{53}$

52 Gnisci 2017.

53 Leroy/Wright/Jäger 1961, pl. XXVIII.
As noted by Underwood, the vegetation above the Tempietto, which evokes the garden of paradise and the life-giving properties of the sepulchre of Christ, appears in illustrated Latin, Armenian, Georgian and Syriac manuscripts, as well as on one of the Monza ampullae. ${ }^{54}$ Among the examples discussed by Underwood, the closest parallels to the Metropolitan Tempietto are to be found in an Armenian gospel fragment kept at the Matenadaran ${ }^{55}$ and in the Adysh Gospels. ${ }^{56}$

54 Underwood 1950, 96.

55 Erevan, Mesrop Mashtots Institute of Ancient Manuscripts, MS 9430, fol. 1v. For a discussion and reproductions see Underwood 1950, 89-90, fig. 38; Nersessian 2001, 158, cat. 81. Similarities between this manuscript and the Ethiopian tradition have been observed by Lepage 1987, n. 14. A recent study on the iconography of the Tempietto in the Armenian tradition by Grigoryan 2014 mentions the tempietto in AG-I but mistakenly identifies as 'Gharima II' and attributes to the tenth-eleventh centuries.

56 Adysh Gospels, fol. 5v, for a reproduction, see Underwood 1950, fig. 44. On the manuscript and its dating, see Nordenfalk 1938, 113-116; Blake/Der Nersessian 1942. 


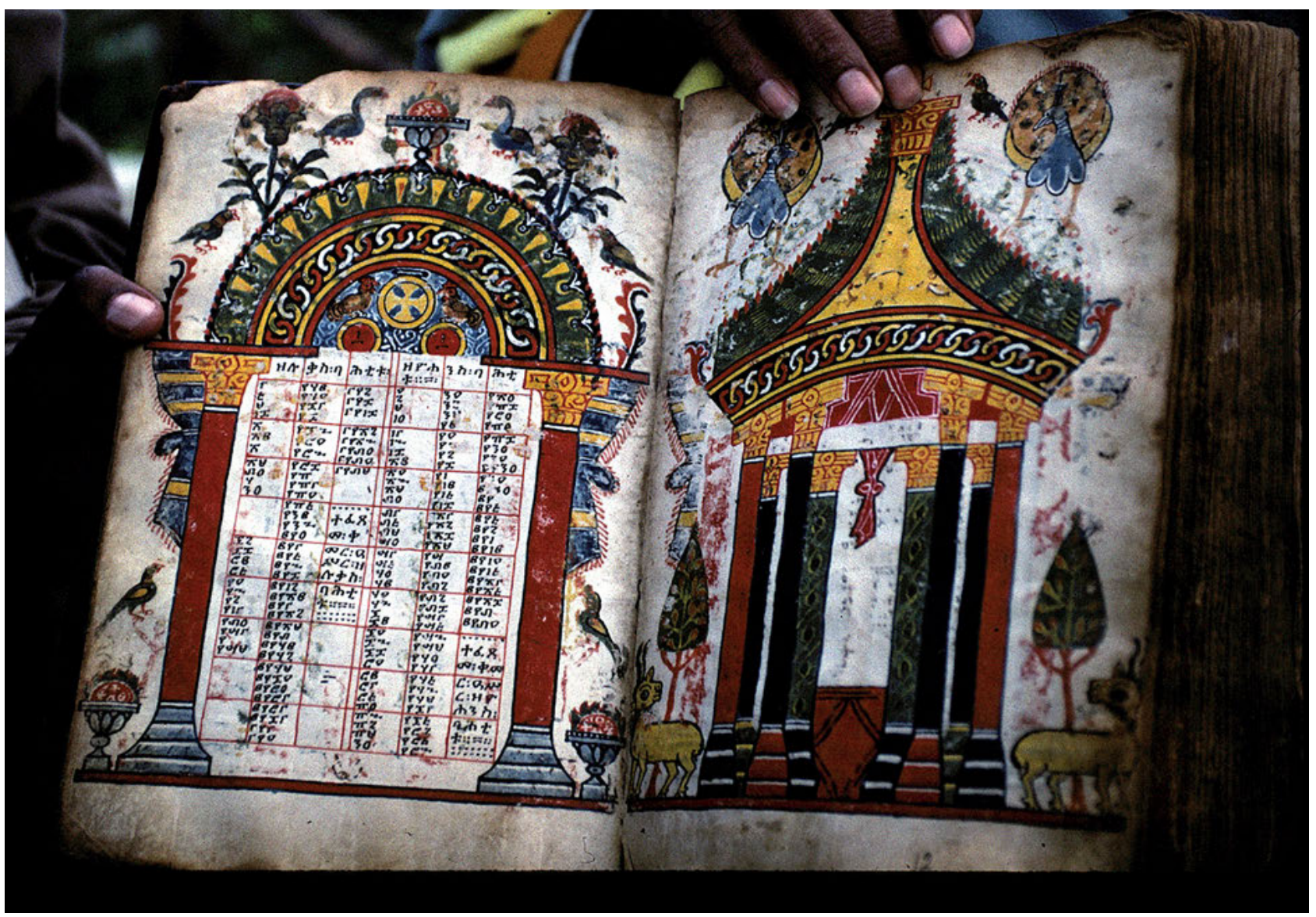

Fig. 6: Four Gospels, Tempietto, Ḥayq, Däbrä Ḥayq ヨsțifanos, fol. 12r, 27.5 × $17.5 \mathrm{~cm}$. () Michael Gervers, courtesy of the DEEDS project.

As for the Rabbula Gospels, rather than the frontispiece with Eusebius and Ammonius analyzed by Underwood, it is the shrubs that grow above the roofs of the structures framing the miniatures of the Selection of Matthew and the Enthroned Christ with Four Monks that recall the Ethiopian examples of this motif. ${ }^{57}$ It is also possible to find a few distant parallels in the Greek tradition, as shown by a Tempietto miniature in a manuscript kept in the Stauronikita Monastery on Mount Athos ${ }^{58}$ or by the architectural frame above a standing Christ in one of the ninth-century leaves inserted in Garrett $6 .^{59}$

The curving lines of the cornice of the Tempietto of the Met leaf appear in most other examples (IMA, BNF-32, DMR, KGL, KTN, UML, WAM-836, MET-1998.66). However,

57 Respectively on fol. 1r and fol. 14r. On the Rabbula Gospels and their dating, see Leroy 1964, 139-140, 153; Cecchelli/Furlani/Salmi 1959; and especially Bernabò 2008, 2014, with further bibliography. 58 For a discussion and reproduction of this miniature, on fol. 2r, see Weitzmann 1935, 19-20, fig. 125. This similarity has also been noted by Lepage 1987, 161.

59 Princeton, Princeton University Library, cod. Garrett 6, fol. 10v. On this manuscript, see Vikan 1973, cat. 1 with further bibliography. in three cases, in DMQ, DSB and AST, these lines appear to have been straightened out, transforming the cornice in an entablature, a development discussed in more detail below, whereas in three other instances, in ZGL, IES-3475 and BSS, the cornice is replaced by a semi-circle. ${ }^{60}$

In the latter cases, due to these modifications, the sense of depth of the Tempietto in AG-I, still vaguely discernible in some of the early Solomonic miniatures such as DMR and IMA, is lost. This results in bi-dimensional structures that are more akin to the arcaded frames of the Eusebian apparatus. On the one hand, this would seem to suggest greater distance from the model on which the Tempietto on the Met leaf is based, or, at any rate, difficulty with the principles of perspective. On the other, it shows that the artists read and understood the Tempietto as an integral part of the Eusebian system. ${ }^{61}$ Such adaptations shed light on the processes of reinvention and

60 This also occurs in a reproduction of a Tempietto miniature from a private collection published in Appleyard 1993, 13.

61 This point has a bearing on the presence of extensive errors in the Ethiopian canon tables, as argued also in Gnisci 2018, n. 10. 


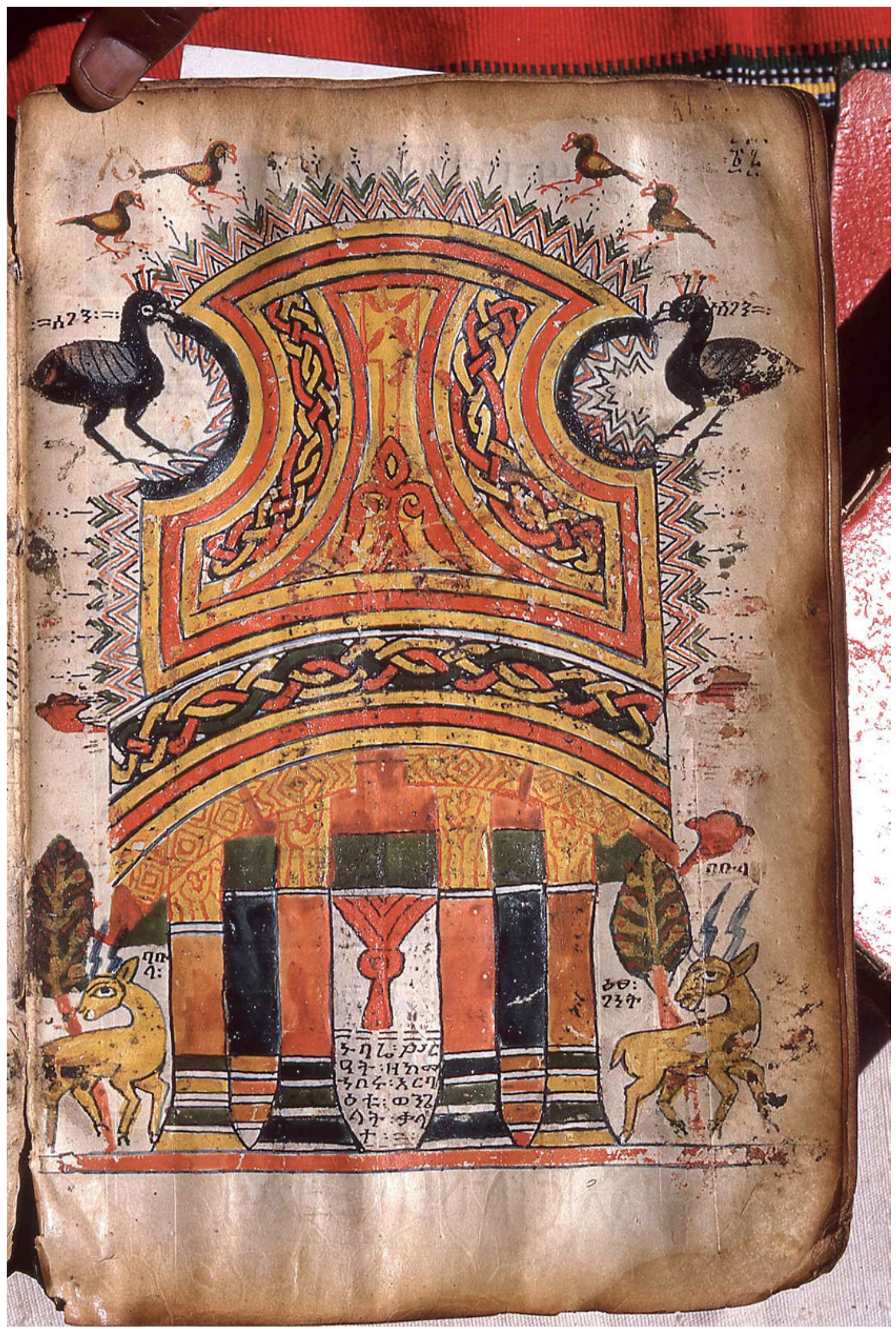

Fig. 7: Gospel book, Tempietto, Addis Ababa, National Library, MS 28, fol. 14r, $29 \times 19.5 \mathrm{~cm}$. (C) Stanislaw Chojnacki, courtesy of the Vatican Library. 


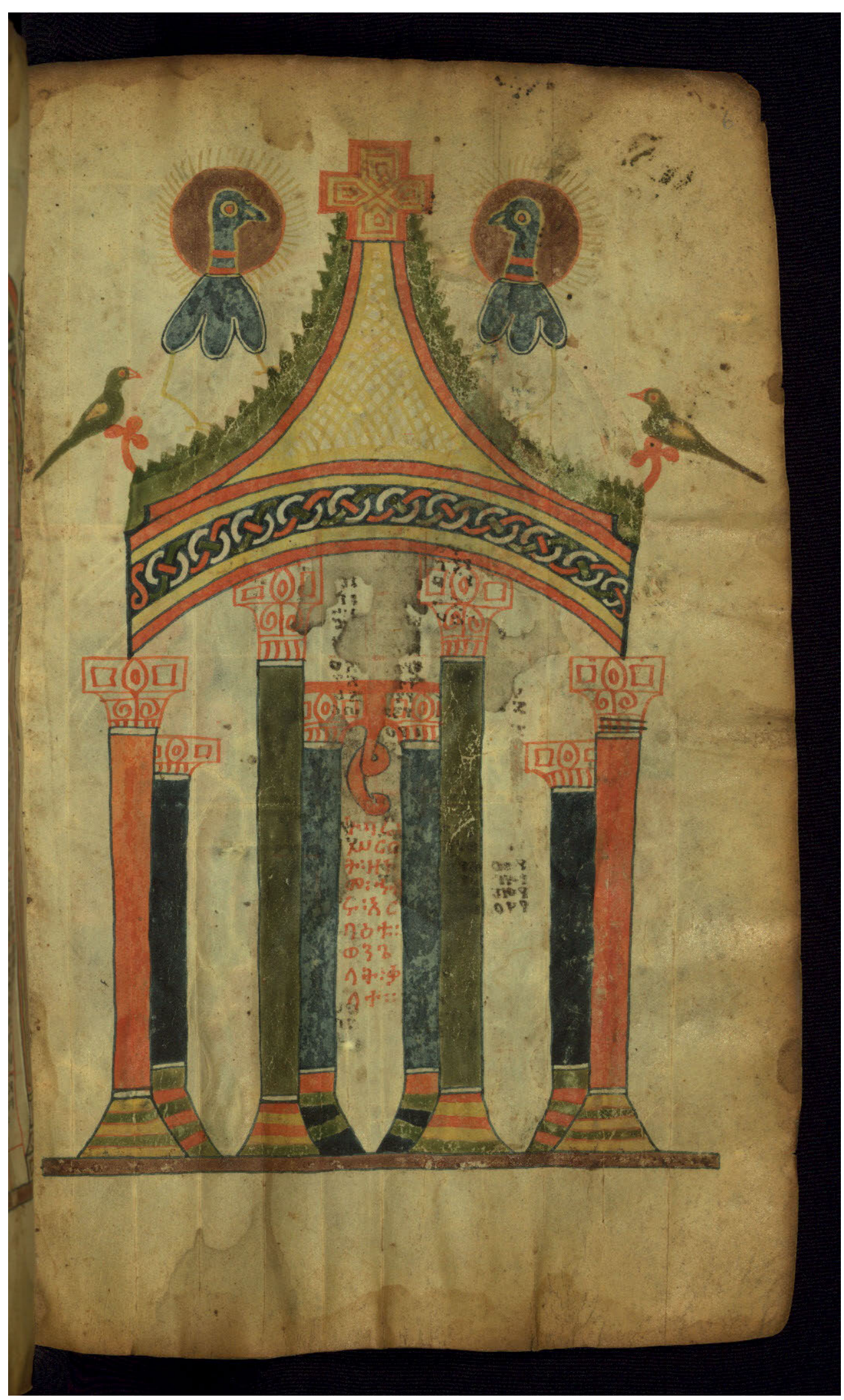

Fig. 8: Gospel book, Tempietto, Baltimore, The Walters Art Museum, W.836, fol. 6r, $26.6 \times 16.5 \mathrm{~cm}$. ( ) The Walters Art Museum. 
reinterpretation which shaped the transmission of visual culture during the early Solomonic period.

In truth, the lack of concern for structural verisimilitude of Ethiopian artists active during the early Solomonic Period is evident in most of the cases listed in Table 1. It is most evident in WAM-836 (Fig. 8), where the superstructure of the Tempietto rests only on the two front columns while the remaining six columns have lost their original function. In this instance, it is significant that the illuminator felt compelled to retain the eight columns of his model even though he was unfamiliar with the type of structure he had to copy and had no interest whatsoever in verisimilitude.

Even when the building preserves traces of pseudo-perspective, it is probably because the artist retained some features of his model with greater accuracy, since Ethiopian art in this period lacks depth. For instance, in the Met leaf, IMA and DMR (Figs 1-2, 6) -which like WAM-836 retain the eight columns of the original model (Fig. 8) -the columns at the back of the tholos are detached from the cornice they should support. This does not occur in MMG (Fig. 10), MET1998.66, UML and KGL, in which the back four columns are missing. For this latter group of miniatures, the filling of the space between the front four columns attests to the presence of back columns in the prototype from which they derive. ${ }^{62}$ These four miniatures, like WAM-836, show us how Ethiopian artists responded to copying details of images they did not fully grasp. ${ }^{63}$

The above hypothesis can be confirmed by looking at KTN, BNF-32 and IES-3475, in which the bases of the columns-six in the two former cases and eight in the latter-are still visible even though the capitals have been omitted..$^{64}$ These errors are of significance for understanding the model-copy relationship in early Solomonic Ethiopia. On the one hand, the reiteration of such mistakes suggests that artists used whatever copy they had at their disposal, even ones presenting such flaws, rather than feel bound to find and reproduce what a modern viewer might consider to be the 'best' model. On the other, it shows that they valued reproduction per se, even when the results of

62 Leroy 1957, 186, overlooks this development and interprets the lozenge pattern between the columns in KGL as a space filler.

63 Evidently, these phenomena lie at the root of these transformations, but once the transformation occurred in one miniature, it is likely that it was replicated by other artists through processes of copying. However, the exact line of transmission remains to be reconstructed and this will be possible only once all these illuminated gospels have been subjected to a detailed textual, codicological, and iconographic analysis.

64 Heldman 1993b, 131 also suggests that IES-3475 is based on an eight-column archetype. this process of imitation produced an image that was far from identical to its model.

Depth is abolished, and the back four columns are absent in DSB (Fig. 9) and AST. In BSS and PC-3 the Tempietto only has two columns, thus appearing to be even more distant from its four- or eight-column prototype. However, in these latter two cases, and possibly also in WAM-836, the placing of the roof on two columns may be only partly due to unintentional errors in the copying of the miniatures. In fact, since it is safe to assume that most early Solomonic Ethiopian illuminators had never seen a tholos, they may have intentionally decided to replicate the features of the arches of the Eusebian apparatus in their rendition of the Tempietto.

Indeed, both the transformation of the cornice into an arch, discussed above, and the reduction from eight or four columns to two, may have been introduced because their makers wanted to represent a structure that made sense to them. To the best of our knowledge, circular plan buildings with a peristyle did not exist in Ethiopia before the sixteenth century. Arches resting on columns or pillars, instead, were often employed in Ethiopian churches for separating the nave from the aisles and the sanctuary. ${ }^{65}$ Furthermore, the motif of the arch supported by columns, employed in the framing of the Eusebian apparatus, was often employed in Ethiopian illumination to represent or symbolize the sanctuary. ${ }^{66}$ Therefore, the transformation of the tholos into an arch which occurs in Ethiopian miniatures of the Tempietto helped to reinforce rather than weaken the ecclesiastical symbolism of this image.

Since the distortions and transformations described above are more evident in some manuscripts from the end of the fourteenth century, such as MMG, BSS and PC-3, and since they become widespread in gospel books of the fifteenth century, it would seem reasonable to look at the turn of the fifteenth century to understand the causes of this development, were it not for the fact that similar phenomena also occur in the earlier versions of the Tempietto preserved in DLB and AG-I.

Although the Tempietto miniature in DLB is not in a good state of preservation, it appears that the artist represented only the front four columns of the tholos, whereas the back of the cornice, visible in some of the early Solomonic miniatures, has been omitted. Similarly, the earlier version of the Tempietto in AG-I has four columns-though this tholos seems more solid than the one in DLB because of the greater quality of the illumination and because in this instance the back of the cornice has not been omitted.

65 Phillipson 2009; Fritsch/Gervers 2012.

66 Gnisci 2015a, 2015b, 486-487. 


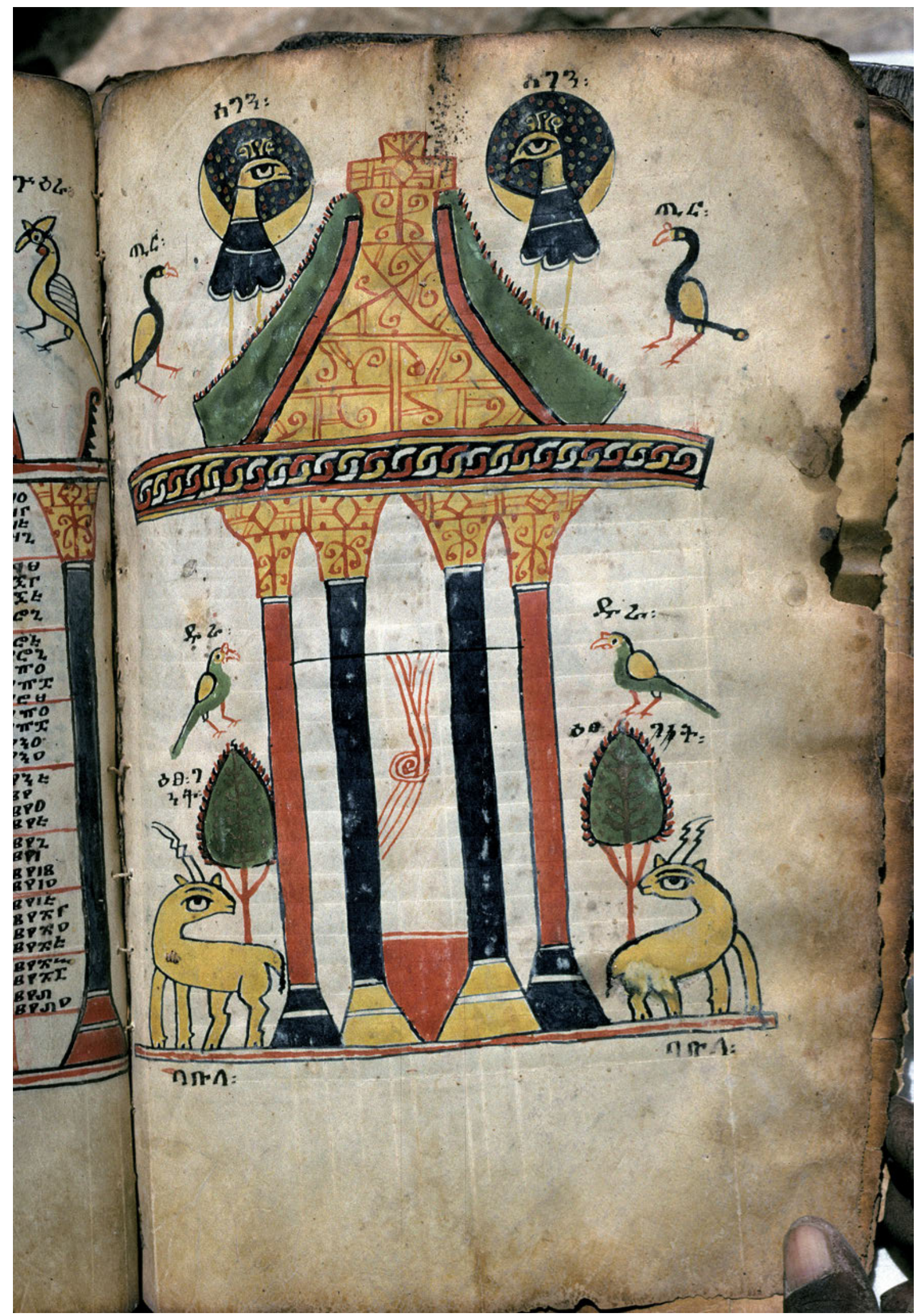

Fig. 9: Gospel book, Tempietto, Șəra', Däbrä Șärabi, fol. 10r, 34 × 22 cm. @ Michael Gervers, courtesy of the DEEDS project. 
Nevertheless, even the Tempietto in AG-I is not devoid of architectural incongruities, the most evident being that the bases of the front columns are covered by the bases of the lateral columns. ${ }^{67}$

Setting aside in the present context the questions of where, by whom, and for whom AG-I was produced, if such question can ever be fully resolved, the above observations allow us to draw some significant conclusions. ${ }^{68}$ First, that the Tempietto on the Met's leaf and its closest relatives, DMR and UML, with their eight columns, cannot be based, or at least cannot be entirely based, on AG-I or on DLB. Second, that the disappearance of the back four columns in some early Solomonic manuscripts may not be entirely due to miscopying but could also be related to the influence of different models. And third, in the light of the architectural incongruities visible in AG-I, that the sources of some of the awkward errors visible in most of the early Solomonic miniatures may well date back to the Aksumite period. ${ }^{69}$

Taking a step further, on hypothetical grounds, it is even possible to ask whether the eight-column Tempietto which appears in early Solomonic gospels reached Ethiopia during the Aksumite period, possibly through the same manuscript which transmitted the short cycle, since they appeared together in the manuscript from which the Met's Tempietto derives and in other examples such as DMR and WAM-836.

To answer this question, it is necessary to attempt to determine when the archetype for the eight-column Tempietto appearing in early Solomonic gospel books reached Ethiopia, from whence it came, and what were its original features. This type of iconographic analysis has to be carried out cautiously as this motif was used over a long period of time and different types of phenomena may have shaped its development during its transmission, as already shown above.

In fact, it is necessary to avoid assuming $a$ priori that all the features of a late version of a subject necessarily reflect a 'lost' archetype or that Ethiopian artists operated in fixed ways. ${ }^{70}$ Lowden, in discussing the transmission

67 The paint in this area is badly damaged, but the bases of the lateral columns are still clearly discernible.

68 For McKenzie/Watson 2016, 104, the artist who painted AG-I was an Ethiopian, but the question remains open to debate.

69 McKenzie/Watson 2016, 102, take this as an indication that AG-I is later than AG-III. A recent study has shown that Ethiopian artists could also 'correct' errors or incongruities in their sources, Gnisci 2017, 90.

70 Probably the best-known example of pushing this type of analysis too far is the study of the Florence Diatessaron by Nordenfalk 1968, which was retracted after Schapiro 1973, exposed the weakness of of visual knowledge in Byzantine manuscripts, rightly cautions us against thinking of the artist as a 'slave to his model' ${ }^{71}$ This remark also applies to Ethiopic manuscripts, since the evidence discussed here shows that Ethiopian artists operated in different ways when copying an image, which could include unintentionally making errors, intentionally amending errors or details, and drawing from multiple sources. ${ }^{72}$

It must therefore be acknowledged that even careful scrutiny will leave some unresolved issues or open questions. Nevertheless, it is clear that at the turn of the fourteenth century Ethiopian artists valued the Eusebian apparatus and its decorative features or they would not have taken it upon themselves to reproduce features, such as the tholos, with which they were unfamiliar. If we bear this in mind and look at what the various miniatures of the Tempietto have in common as well as what makes them distinct, we may draw at least some reliable conclusions about their origin and transmission.

For instance, the very fact that early Solomonic illuminators had difficulties in rendering and grasping the structure of the eight-columned Tempietto, as is particularly evident in WAM-836 (Fig. 8), makes it highly unlikely they were responsible for the introduction of this detail, which must surely derive from an earlier archetype. ${ }^{73}$ For the same reason, the grille which appears in several early Solomonic examples of this subject, but not in AG-I and DLB (Figs 4-5), must have been a feature of the archetype on which the eight-columned tempiettos are based.

The detail of the grille has been associated, with reason, to miniatures of the Tempietto found in other traditions ${ }^{74}$ and to the representations of the Tomb of Christ found in Late Antique art. ${ }^{75}$ The resemblance between the

several of its arguments.

71 Lowden 2002, 70.

72 A similar point has been recently made in Gnisci 2017, 91-98.

73 Underwood 1950, 90, argues that the eight-columned structures visible in Latin and Armenian gospels are close enough to justify the assumption of a 'common heritage'. A related observation for the Ethiopian tradition is found in Lepage 1987, 161, who is correct in arguing that the archetype would have been similar to the Tempietto miniatures in such manuscripts as the Second Etchmiadzin Gospels, discussed above, or the Godescalc gospel lectionary in the Bibliothèque nationale de France, Nouv. acq. lat. 1203, fol. 3v. For a discussion and reproduction of the Godescalc lectionary, see Underwood 1950, fig. 30; Kessler 2016, 22-39.

74 For example, in the Godescalc gospel lectionary and in the Adysh Gospels.

75 The literature is too extensive to be given in full, see Underwood 1950, 92; Grabar 1958, pls 5, 9, 11-16, 18, 22, 24, 26, 28, 34-39, 45, 47, 55; St. Clair 1979; Wilkinson 1972; Ousterhout 1990; Iacobini/Perria 1998, 59-61. 


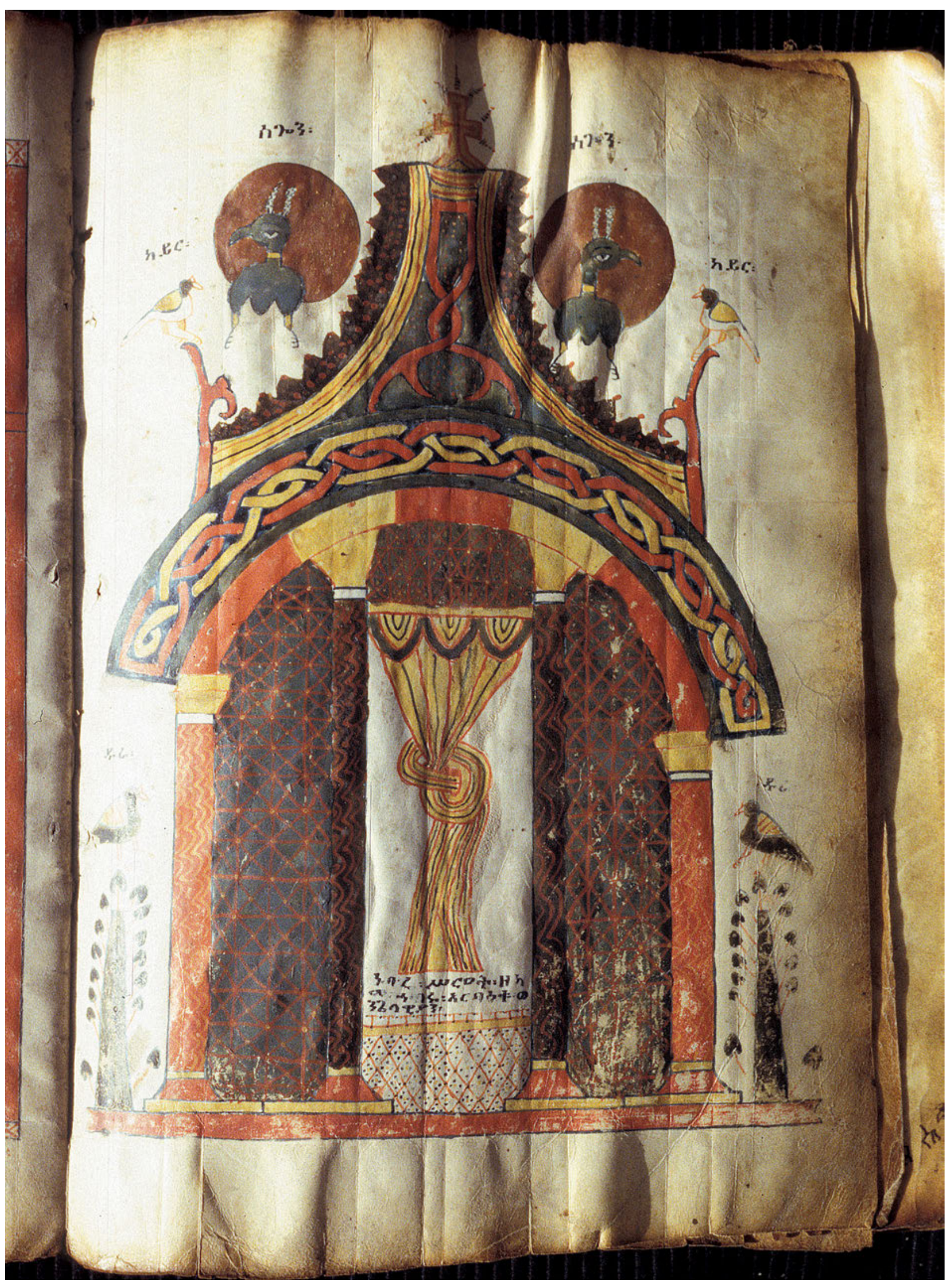

Fig. 10: Gospel book, Tempietto, Amba Dära, Maryam Mägdälawit, fol. 18r, $36.4 \times 27 \mathrm{~cm}$. @ Michael Gervers, courtesy of the DEEDS project. 
Ethiopic version of the Tempietto and works of art from different contexts and periods of time points towards a common derivation from Late Antique examples. Indeed, while it is difficult to be precise about the date of the archetype of the Met's Tempietto, to judge by these and other features discussed below, a fifth or sixth century date is not inconceivable.

Regrettably, due to the lack of earlier examples, it is not always possible to be so confident about the origin of some of the features of the Tempietto in early Solomonic gospel books. ${ }^{76}$ This can be illustrated by returning to the argument that the four-columned Tempietto which appears in early Solomonic manuscripts is a deviation from the eight-columned version found in the Met leaf. The visual evidence examined above lends itself to this line of reasoning: the examples of four-columned Tempiettos are stylistically and iconographically related to the eight-columned structures and there are several miniatures, such as the one in BNF-32, in which the bases of the columns are represented even though the columns to which they belonged are not shown.

However, it cannot be entirely ruled out that four-columned versions of the Tempietto, such as those which appear in AG-I (Fig. 4) and DLB (Fig. 5), did not exert some sort of influence on early Solomonic artists. In other words, the appearance of the four-columned Tempietto in illustrated Ethiopic gospels of the fourteenth and fifteenth centuries could stem from miscopying, from an intentional conflation of models, or from a combination of these phenomena. ${ }^{77}$

Further evidence showing that early Solomonic illuminators could misunderstand their model or conflate multiple artistic sources is provided by the Tempietto in DMQ. ${ }^{78}$ Most witnesses from this period have a tholos like the ones that appear in AG-I and DLB. In contrast, several features of the Tempietto in DMQ, such as its gabled doorway, recall the structure depicted in AG-III (Fig. 3). ${ }^{79}$

76 Cf. Underwood 1950, 244.

77 The possibility of a merging of elements in the Ethiopian version of the Tempietto was first discussed, in a preliminary manner, by Underwood 1950, 104-105, and then by Bausi 2004, 53-54. For some remarks on the conflation of different sources in a theme in Ethiopian illumination see Lepage/Mercier 2012b, 131; Gnisci 2017, 91-94, for the merging of themes in one miniature see Leroy 1955, 131-134; Ricci 1959, 106-111; Gnisci 2014, 217; 2018, 380-381.

78 In the panorama of Christian manuscript illumination, the conflation of themes or motifs is not a phenomenon that is unique to Ethiopia, see for instance Raby/Brock 2014, 28; Schapiro 1973, 528; Weitzmann 1947, 162-163.

79 This probably also occurred in AST and BSS, but the evidence is not as conclusive as it is for DMQ. Leroy 1962 is oblivious to this possibility. For Underwood 1950, 110, the conical roof and cornice with
The dark areas below and at the sides of the Tempietto in $\mathrm{DMQ}$, for instance, must derive from a model which featured walls and a stepped access like AG-III.

Another feature that DMQ has in common with AG-III is the position of the antelopes. In fact, in both manuscripts, the antelopes are placed below the doorway, rather than at the sides of the building as in most other examples of this subject in early Solomonic manuscripts (Figs 1-2, 6-7, 9). ${ }^{80}$ Equally intriguing is the detail of the cross which appears above the doorway of the DMQ Tempietto. Such a detail is absent in AG-III and could instead be related to the cross that is visible in AG-I (Fig. 4) and in several other examples of the Tempietto discussed here (Figs 1-2, 6, 8, 10), thus bolstering the claim that Ethiopian illuminators could draw elements from multiple sources.

The cross standing at the peak of the roof of the tholos in AG-I finds parallels in several non-Ethiopian examples of the Tempietto. ${ }^{81}$ It appears also above the Tempietto of the Met leaf and in several other early Solomonic gospel books, such as DMR. More frequently, however, early Solomonic illuminators misunderstood this element and transformed the capital on which the cross stands into the cross itself. This occurs in KGL and BNF-32, and possibly also in BSS and WAM-836 (Fig. 8).

Like the transformation of the cornice into an arch described above, these iconographic developments were probably induced by distinct but related causes. First, the illuminators misunderstood this feature of the tholos since the idea of a building surmounted by a capital was alien to them. The Tempiettos in DSB (Fig. 9) and UML manifest this kind of difficulty. In UML, the capital is still visible, but the small pattee cross that surmounts it has little in common with the cross of AG-I or the Met leaf. Rather, its combination with the horizontal band of the capital anticipates the large cross-shaped element which appears in manuscripts like BNF-32. Thus, the transformation of the capital topped by a small cross into a larger cross may have been partly due to lack of accuracy in the copying process and partly due to the desire of the illuminators to produce an image that made sense to them.

Although remarked upon very little up to this point, the identification of the phenomena of miscopying and

curved sides are 'tell-tale' features of the tholos.

80 As the evidence indicates that DMQ is indebted to AG-III, it is possible that this manuscript, or a relative, also exerted an influence on the iconography of the Tempietto in manuscripts such as BSS and AST. 81 For instance, in the Godescalc Lectionary, in the Etchmiadzin Gospels, and, in a corrupted form, in the Second Etchmiadzin Gospels, discussed above. To this list, one can add the Greek gospels in Venice, Biblioteca Nazionale Marciana, MS Gr. I 8, fol. 3r, reproduced in Weitzmann 1935, fig. 92. 


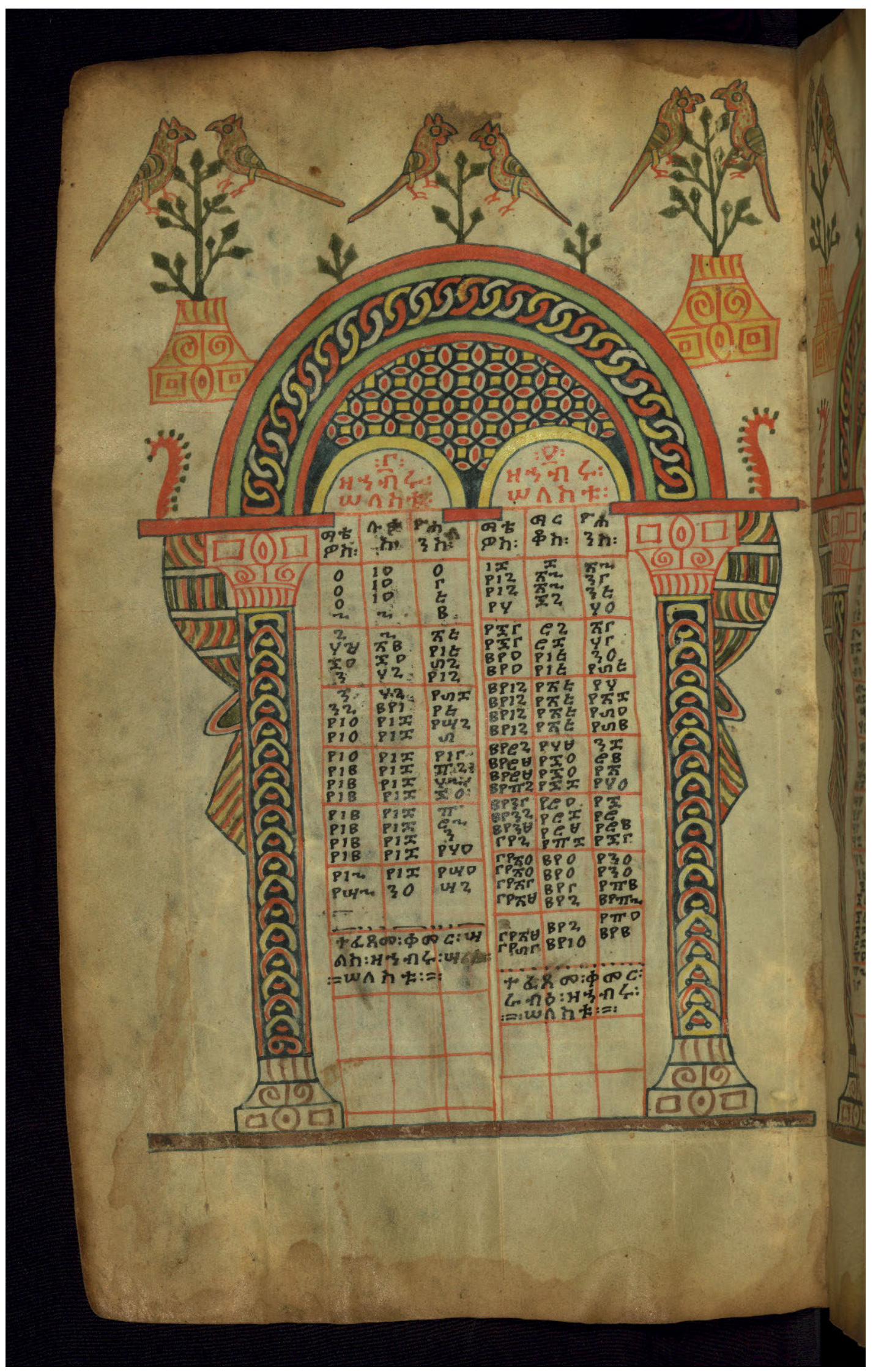

Fig. 11: Gospel book, Eusebian Canons III and IV, Baltimore, The Walters Art Museum, W.836, fol. 3v, $26.6 \times 16.5 \mathrm{~cm}$. ( ) The Walters Art Museum. 
conflation in fourteenth- and fifteenth century illustrated Ethiopic gospel books is hardly surprising when considering that similar phenomena occur in the text of the gospels. In fact, Ethiopic gospels present numerous variant readings stemming largely 'from internal corruption'. ${ }^{82}$ As for conflations, as early as the nineteenth century Guidi and Hackspill had noted how Ethiopian scribes tended to conflate rather than substitute new readings with old ones. ${ }^{83}$

Their impressions were confirmed and expanded upon by Zuurmond, who observes that 'the average Ethiopian scribe must have almost permanently mixed the text he was copying with the text he had in mind, or even with the text of another manuscript to which he had immediate access' ${ }^{84}$ It is reasonable to suggest therefore that a certain overlapping of tendencies, between scribal and artistic practices, occurred in those largely monastic contexts, where manuscripts and, more specifically, gospel books were produced and decorated. ${ }^{85}$

Once it is recognized that unintentional copying errors and intentional conflations and transformations occur in Ethiopian illustration of the early Solomonic Period, it becomes necessary to scrutinize all details of the iconography of the Tempietto with considerable caution before suggesting the origins of some of its features.

For instance, it would be negligent not to observe that the triangles appearing around the superstructure of the Tempietto in several miniatures (KTN; AST; MMG; ZGL; PC-3; Figs 7, 10) recall the pattern visible on the synagogue niche depicted on the mosaic from the Beth Alpha synagogue. ${ }^{86}$ The triangular pediment in this mosaic also recalls the doorway which gives access to the church-structure depicted in AG-III (Fig. 3), often described as a unicum in Christian art. ${ }^{87}$ In AG-III access to the sanctuary is granted by a flight of steps. This feature also appears in other early Jewish works, namely in a relief from Beth She'arim and in the mosaic from the Hammat Tiberias synagogue. ${ }^{88}$ There-

82 Zuurmond 1989, I, 39.

83 Hackspill 1896; Guidi 1888, 37.

84 Zuurmond 1989, I, 39.

85 For an introduction to the manuscript culture of Ethiopia, with further references, see Bausi 2014.

86 For a reproduction and discussion, see Hachlili 1976, fig. 10; Branham 1992, 384-389. The former author argues that the Beth Alpha mosaic represents the ark rather than the niche of the Synagogue, but, considering that this mosaic features elements such as a hanging lamp, acroteria, and a conch, such a suggestion is unconvincing. 87 But probably to be compared with the building with stepped access which represents the House of the Lord in Utrecht, University Library, MS 32, fol. 75v; on which see Benson 1931; Fiaccadori 2003, 187; see also the parallels discussed in Flood 2012, 266-267.

88 For a discussion and reproductions, see Hachlili 1976, Figs 7, 9; Milson 2006, 58, 66-68. fore, while a gradual process of adaptation and simplification appears to be the most likely source for the triangle patterns visible in some Ethiopian examples of the Tempietto, one cannot completely dismiss the possibility that it derives from a different model.

\section{Interlace motif}

One of the most distinguishing elements of the Tempietto on the Met leaf is the interlace pattern decorating its cornice. This is a recurring feature in Ethiopic manuscripts of the early Solomonic Period, appearing with minor variants in IMA (Fig. 6), BNF-32, BSS, DMR (Fig. 2), DSB (Fig. 9), UML, WAM-836 (Fig. 8), PC-3 and, in a more altered form, in KTN (Fig. 7), MMG (Fig. 10) and IES-3475. Only KGL and MET-1998.66 have a lozenge pattern instead of the braid motif. ${ }^{89}$ Nevertheless, its systematic appearance in the other manuscripts further reinforces the impression that this group of miniatures largely depends on a common source. Significantly, knots of interlace are not visible in two of the manuscripts that seem to be most heavily indebted to different sources, namely in DMQ and AST. At the same time, the decorative patterns on the cornices of AG-I (Fig. 4) ${ }^{90}$ and DLB (Fig. 5), ${ }^{91}$ although not

89 This is one of several features that these two miniatures have in common that are absent in other manuscripts, suggesting a closer relation between them. Establishing the precise relationship between the illustrations in Ethiopic gospels is a complex task yet to be carried out, even more so as every illuminator introduced some small variants. For instance, the scene of the Entry in Jerusalem in ZGL (fols 11v-12r) is closely related to that in KGL (fols 15v-16r). Yet, the versions of the Tempietto in these two manuscripts have little in common. Only when these complex relationships have been mapped out will it be possible to provide a more accurate picture of the development of manuscript illumination in Ethiopia during the early Solomonic period. In this respect, the relationship between KGL and MET-1998.66 is particularly interesting. While the Tempietto miniatures in these two manuscripts have a number of elements in common, such as the use of a split-palmette motif to decorate the roof, the artist of MET-1998.66 clearly misrepresents many features of the Tempietto: the bases of the columns are rendered as an abstract chevron pattern and it is impossible to determine whether the two bands of interlace pattern at the outer sides of the Tempietto are to represent the back columns of the building or the trunks of the trees in front of which the antelopes stand in KGL.

90 The similarities between the decorations of AG-I and a number of non-Ethiopic gospel books are discussed in McKenzie/Watson 2016. The peacock tail motif which appears on the cornice of its Tempietto is a motif attested in Byzantine art, on which see Iacobini and Perria 1998, 50, with further bibliography.

91 The meander which decorates the Tempietto in DLB, which recalls the decoration of the outer band in the canon tables of AG-I, 
related to the interlace of the Met leaf, show that miniatures of the Tempietto with a decorated cornice circulated during the Aksumite and Zagwe Periods.

The recurring use of interlace patterns in early Solomonic miniatures of the Tempietto makes it reasonable to ask whether this feature was part of the archetype on which they are based. Thus far, the only remarks on the presence of interlace patterns in the Ethiopian version of the Tempietto are found in an article on the decoration of Ethiopic gospels of the early Solomonic period by Lepage, who suggests that these could be the only 'original' feature introduced by Ethiopian artists..$^{92}$ Then, in apparent contradiction to his previous statement, he argues that such ornamental patterns were not created in Ethiopia but were transmitted from 'unknown oriental manuscripts' painted in a style akin to that of the early gospel fragments preserved in the British Library's Add. MS 5111/1. ${ }^{93}$ However, as shown below, the comparison is not apt. Lepage points out more convincing affinities with third- to fifth-century mosaics and textiles from Antioch and Palestine, but cites no examples to support this statement. Thus, his comments fail to present an adequate analysis of the evidence.

To unravel the issue of the origin of the interlace patterns appearing in Ethiopian examples of the Tempietto the first point to be made is that almost identical patterns are also found on the arches decorating the preceding Eusebian apparatus (Figs 2, 11). More specifically-to confine the discussion to those witnesses which still preserve a Tempietto at their end ${ }^{94}$-we see it in IMA, DMR, DMQ, NMB-2034, KTN, BNF-32, MMG, UML, DSB and BSS. ${ }^{95}$ In some manuscripts the geometric decorations extend beyond the arch. For instance, the chain pattern extends on the lintels in DSB (fols $5 \mathrm{r}-6 \mathrm{r}$ ) and on the columns in W-836 (fols 3v-5r; Fig. 11), MMG (fol. 9v) and MET-1998.66 (fols 11r, 12v-13r, 15v).

This observation suggests three main possibilities: a) that an interlace pattern was an integral part of the Eusebian apparatus and Tempietto in the model on which manuscripts such as IMA, BNF-32 and DMR are based;

is widely attested in other Christian traditions and can be compared with the tholos in the second Etchmiadzin Gospels.

92 Lepage 1987, 162.

93 Lepage 1987, n. 26. On this manuscript, see Nordenfalk 1938, 127-146, 1963; Weitzmann 1977, 19, 29, 116, pl. 43; Lowden 2007, 24-26. Elsewhere, Lepage and Mercier 2012, 106, argue that Christian-Arabic art influenced the interlace pattern of the Tempietto, but furnish no evidence in support of this claim.

94 Interlace patterns appear also in a number of fragmentary canon tables which will be discussed in a separate study.

95 In KGL the lozenge pattern which decorates the cornice of the tempietto also appears in the Eusebian apparatus. b) that this feature was originally present only in the canon tables and was introduced later in the iconography of the Tempietto as a result of the process, described above, which led Ethiopian artists to flatten the tholos into a two-dimensional structure and treat it as an additional canon table arch; or c) that this feature was introduced at a later stage in both the canon tables and the Eusebian Apparatus.

Although this question remains open to debate, based on the evidence afforded by Ethiopic manuscripts, the first possibility seems the most likely as the interlace pattern appears in two manuscripts, namely DMR and IMA, that retain features that appear closely related to late antique or early Byzantine painting, such as the pseudo-perspective and the eight columns that have been linked above to the supposed archetype. ${ }^{96}$

What needs to be determined, then, is if the presence of such a feature is compatible with the hypothesis that the archetype of our eight-column tempietto dates to the fifth or sixth centuries, and, to accomplish this, it is necessary to look beyond the evidence afforded by Ethiopic gospels. This issue also has a bearing on our broader understanding of Ethiopian art, since-and this is a point of particular significance that has yet to be examined in detail-the designs appearing on the cornices of the Tempietto appear in the headpieces used to decorate Ethiopic manuscripts (haräg), ${ }^{97}$ on engraved crosses tentatively dated to the twelfth or thirteenth centuries, ${ }^{98}$ and in wall paintings, as shown by the late twelfth- or early-thirteenth century decorations in the church of Betä Maryam in Lalibäla. ${ }^{99}$

96 On the early appearance of geometric patterns in the canon tables, see Frantz 1934, passim.

97 Although the two questions are clearly interrelated, the subject of the headpieces in Ethiopic manuscripts will be the object of a separate discussion. In this context, let it suffice to refer to the main studies on the topic, Uhlig 1984, 1989; Perczel 1989; Zanotti-Eman 1992, 1993, and to note that some early Ethiopic manuscripts feature the type of braid of two strands which appears in the canon tables and Tempietto, as in London, British Library, Or. 691. Zanotti-Eman 1998, 149-150, has pointed out that curtains, or curtain rings, appear in some of the haräg which frame the text columns in Ethiopic manuscripts of the fifteenth and early sixteenth centuries. This observation may have a bearing on our understanding of the use and symbolism of frames that surround the text as an arcade, but does not, as she insists, shed light on the question of the appearance of haräg in Ethiopic manuscripts. If anything, it shows that early Solomonic illuminators felt at liberty to adapt and reemploy the decorative and figurative elements borrowed from earlier gospel books in new material contexts.

98 For a discussion and reproduction of the crosses, see Chojnacki 2006, fig. 38; Lepage/Mercier 2012b, figs 2.7, 5.56.

99 On the wall paintings of Betä Maryam, which are dated on stylistic grounds, see Lepage 1999; Semoglou 2009. In passing, it is 
Interlace motifs are of course attested in Greek, ${ }^{100}$ CoptoArabic, ${ }^{101}$ Armenian ${ }^{102}$ and Syriac manuscripts, ${ }^{103}$ making it difficult to pinpoint an origin for this kind of pattern. Interlace patterns, often used to frame the same types of plants and animals which populate the Eusebian Apparatus, have also been widely attested in many mosaics of the fifth and sixth centuries found in North Africa and the Middle East. ${ }^{104}$

Yet, if points of contact with these areas are to be expected, it is perhaps more surprising that some of the closest parallels to the Ethiopic tradition are found in Latin gospel books. Indeed, many Latin codices, such as the Maeseyck Gospels ${ }^{105}$ and the Harley Golden Gospels, ${ }^{106}$ feature polychrome interlaced bands on the arches or columns of their canon tables. The ornamental decorations in these gospels have been associated, with good reason, with manuscripts produced in northern European

worth noting that the paintings in some Ethiopian churches exhibits an indebtedness to the decorative motifs of the Eusebian apparatus, as is evident in the paintings in Qorqor Maryam. On this church, see Tribe 1997. A more detailed discussion of the transmission of decorative motifs across different media in early Solomonic art is found in my forthcoming study entitled 'Copying, Imitation, and Intermediality in Illuminated Ethiopic Manuscripts from the Early Solomonic Period'.

100 A small number of Greek manuscripts, such as the ones in the Vatican City, Biblioteca Apostolica Vaticana, gr. 334, and Vienna, Österreichische Nationalbibliothek, Theol. gr. 154, feature patterns that are particularly close to the ones found in early Solomonic illuminated manuscripts; for a more detailed discussion, see Frantz 1934, 50-54. See also the decorations of several late antique sarcophagi in Ravenna in Kollwitz/Herdejürgen 1979, pls 69-70, 79, 86.

101 For some examples, see Leroy 1974, pls 2-4, 6, 10,12, 15, 22-23, 31, 38. See also the Nubian fragment in Berlin, Staatsbibliothek, Ms. or. quart. 1020.

102 A simple interlace pattern appears already in the gospels of Queen Mlk'e, Venice, Abbey of San Lazzaro degli Armeni, Bib., MS 1144/86, fol. 3r. For an overview of the Armenian tradition, see Weitzmann 1933; V. N. Nersessian 1987.

103 For instance, the canon tables in the Rabbula Gospels, see Cecchelli/Furlani/Salmi 1959, fol. 2b; and the ninth-century canon tables reproduced in Bernabò 2017b: 321, fig. 1; but also as bands and decorative elements in later manuscripts, see Raby/Brock 2014, pls 16-18, 35-44. For a more general overview of the tradition, see Leroy 1964.

104 E.g. the examples in Piccirillo 1993; and Dunbabin 1978.

105 Maseyck, Church of St Catherine, Codex A, fols 2r, 3v, 4v, 5v; Codex B, fols 1r-3v, 5r-5v, 6v, see Nordenfalk 1938, 180, n. 1; Netzer 1994, 65-77; Brown 1996, 74, 80, 90. Evidently, a more detailed discussion of all the parallels and differences would take up an entire contribution.

106 London, British Library, Harley MS 2788, fols $8 \mathrm{v}-9 \mathrm{r}$. On this manuscript, see Goldschmidt 1928, I, 11, pls 35-37; Koehler 1958, II, 56-69, pls 42-66; McGurk 1993, 105-107; Lowden 1988, 100. or Insular contexts and to the patterns used in local metalworking. ${ }^{107}$

However, similar ornamental patterns can also be seen in manuscripts produced in Italy, as illustrated by an early eight-century gospel in the Vatican Library, ${ }^{108}$ and in Italian sculpture of the fourth to the seventh centuries, as shown by the Ciboria from S. Apollinare in Classe in Ravenna and S. Maria in Sovana. ${ }^{109}$ Hence, the possibility of indirect connections between the two traditions should be taken into consideration. ${ }^{110}$

While many have commented on the existence of similarities in the decoration of Insular and Ethiopic manuscripts, ${ }^{111}$ Werner, in his insightful studies of the Book of Kells and the Book of Durrow, has been one of the few to convincingly demonstrate how these similarities are down to mutual dependence on Coptic sources. ${ }^{112}$ The influence of the Church of Alexandria on the development of the Ethiopian Church and its art is too well known to require comment. ${ }^{113}$ Equally well-known is the opinion that Coptic art was influential in the development of pre-Carolingian manuscript illumination. ${ }^{114}$

Hence it is not unreasonable to think that the interlace patterns appearing in Ethiopic and Latin canon tables

107 The literature is too extensive to be given in full here. For an introduction and further bibliography, see Romilly Allen 1904, 162-231; Henderson 1987; Jope 2000.

108 Vatican City, Biblioteca Apostolica Vaticana, Vat. lat. 5465, fols 5r-10v. On the canon tables in this manuscript, see Wright 1979, with additional references. In the context of a discussion of the canon tables, it is also worth noting that braid motifs decorate the arches and sometimes the columns of the copy of the Chronography of 354 .

109 Toesca 1965, 271-296, fig. 256. It is beyond the scope of this paper to go into detail in this matter, but it is evident that the presence of such decorative patterns on baldachins is of interest since they share symbolic and iconographic features with the canon tables and Tempietto. For an overview and further remarks, see Klauser 1961; Bogdanovic 2017.

110 On this point, it is worth noting that a lost Greek text on the History of the Alexandrian Episcopate, hitherto known chiefly from Latin excerpts from a manuscript in Verona, Biblioteca Capitolare, Cod. LX (58), has recently been discovered in an Ethiopic manuscript, see Bausi and Camplani 2016. This is one among several Greek texts which have been preserved in Ethiopic and Latin, Bausi 2016. It is also worth noting that a sixth-century Latin gospel in London, British Library, Harley MS 1775, fol. 15r, although lacking the Tempietto and distributing the canon tables over 18 pages, features an empty canon table at its end like AG-I.

111 For instance, Monneret de Villard 1943; Lepage 1977b, 347.

112 Werner 1969, 1972a, 1972b, 1990.

113 Though see the new valuable evidence presented in Bausi 2006, with further bibliography.

114 Mâle 1917, 33; Porter 1931, 18-20, 79; Krautheimer 1942, 6; Sulzberger 1955; Weitzmann 1966; Rosenthal 1967; Veelenturf 2001, with further bibliography. 
could descend from early Greco-Egyptian models circulating throughout the Mediterranean world. ${ }^{115}$ Among the earliest Greek examples, two of the arches in the incomplete set of canon tables preserved in the Codex Vindobonensis 847 are noteworthy since they present features closely resembling the Ethiopian tradition. ${ }^{116}$ There is a lack of early illustrated Coptic gospel books, but when observing a sixth-century Coptic hanging in the Cleveland Museum of Art, ${ }^{117}$ a sixth- or seventh-century Coptic stela in the British Museum, ${ }^{118}$ or the frames of the middle-register niches in the Red Monastery, ${ }^{119}$ one acquires a sense of what kind of patterns decorated the canon tables of illustrated manuscripts produced in late antique Egypt. ${ }^{120}$

\section{Animals and trees}

The two trees arranged heraldically at each side of the tholos in the Met leaf appear in all early Solomonic examples except AST and WAM-836 (Fig. 8). The fact that the Ethiopic tradition shares this feature with the Armenian, as observed by Underwood, is strongly suggestive of a common ancestry from Late Antique sources. ${ }^{121}$ The frontispiece to the canon tables in the sixth-century Greek gospel book fragment preserved in the National Library of Vienna features two flowering trees beneath the wreath-framed cross. ${ }^{122}$ Such frontispieces may not prove that trees were linked to the Tempietto in the Greek tradition, but they clearly show that pairs of trees were among the elements associated to the Eusebian apparatus in early Byzantine

115 For an overview of the impact of Byzantine art on the West, the classic study is Demus 1970.

116 For a discussion and reproductions, see Zamparo 2018, pls IV, on the columns, and VII, on the left arch.

117 Cleveland, Cleveland Museum of Art, acc. no. 1982.73. For some additional examples, see Rutschowscaya 1990, 83-85, 87.

118 London, British Museum, coll. no. EA54351. The stela also presents the motif of the cross under the arch that appears in a number of Aksumite coins, but it is set against a conch like that which appears in AG-I.

119 Bolman 2006, 16-17, pls 15-18, for a more general discussion of this church and further bibliography, Bolman 2016.

120 The above also shows that-contrary to what Perczel 1989, 6061, argues-the Ethiopian tradition of decorating manuscripts with interlace patterns is unquestionably linked to other traditions. It remains to be established if the guilloche patterns drawn in AG-I and AG-III are coeval with the text they delimit.

121 In addition to the examples given by Underwood, one should mention the figure of Christ with a gospel between two cypress trees in the sixth-century Syriac gospels in Diyarbakir, Turkey Meryem Ana Kilisesi, fol. 1r, discussed in Leroy 1957 and Bernabò/Kessel 2016.

122 Vienna, Österreichische Nationalbibliothek, Cod. 847. See Underwood 1950, 112, fig. 58.
Greek gospel books. ${ }^{123}$ This impression is strengthened by an opening of the canon tables in AG-I (fols 4v-5r), which features the same tree-type that is later found in early Solomonic miniatures of the Tempietto.

Further evidence that the archetype on which the Met's leaf is based belongs to the fifth or sixth centuries is offered by the various animals which populate the miniature. ${ }^{124}$ For instance, the two peacocks with outspread tails that are found in the Ethiopian miniatures, recall similar motifs which appear in the Rabbula Gospels, ${ }^{125}$ in the hexagonal censer from the Sion treasure, ${ }^{126}$ in catacomb paintings, ${ }^{127}$ and at Bagawat in Egypt ${ }^{128}$ in a number of Late Antique mosaics, including the early fragments in the Duomo of Aquileia, the house of the Peacock in Carthage, or the Basilica of Justinian in Sabratha. ${ }^{129}$

Evidently, the Ethiopian tradition is also related to western and eastern examples in which the two peacocks perched above the Tempietto are represented in profile. In this respect, the peacocks that appear above the tholos in the Soissons Gospels or in a mosaic from the Church of

123 More generally, these and other decorative elements found in the Eusebian apparatus circulated quite freely across media. For instance, a sixth-century diptych plaque from the British Museum, coll. no. OA.9999, perhaps produced in Constantinople, features a cross within a wreath bound by lemnisci and placed against a scallop under an arch supported by columns, as already noted in Dalton 1909, 9-11.

124 For a detailed analysis of the names of animals appearing in the Eusebian Apparatus and Tempietto, see Bausi 2004. Leroy's initial hypothesis that the term babula used to designate the antelopes in the early Solomonic illustrations could point to a Syriac origin for the Ethiopian version of the Eusebian Apparatus, was partially retracted by the author himself, Leroy 1962, 199-200, and then convincingly refuted by Bausi 2004, 59-63.

125 For a reproduction, see Cecchelli/Furlani/Salmi 1959, fol. 2a. In the Tempietto in the Soissons Gospels, Paris, Bibliothèque nationale de France, lat. 8850 , fol. $6 \mathrm{v}$, the peacocks are depicted in profile, but the type with the outspread tail is attested on fol. $7 \mathrm{v}$. For a discussion of the canon tables in the Soissons Gospels, see Rosenbaum 1955. Surviving examples of the Eusebian Apparatus in various traditions, including the Ethiopic, typically feature peacocks in profile above the first page of the Letter to Carpianus, as noted by Lepage 1987, 160; Lepage/Mercier 2012, 104.

126 Washington, Dumbarton Oaks, BZ.1965.1.5; Boyd and Mango 1992, 10, 18.

127 See Bisconti 2011, 224, 232, figs 9, 26.

128 Wilkinson/Hill 1983, 161.

129 For a discussion, reproductions, and further examples, see Dunbabin 1978, 104, 165, 166-69, 189-90, figs 92, 166, 170, 194, 197. It remains to be established if the symbolism the peacocks have in early Christian art, as discussed in Underwood 1950, 88, 114, is also at play in Ethiopian art. It is interesting to note that the caged bird motif, which appears in Sabratha and elsewhere, as illustrated in Grabar 1960, is attested in Early Solomonic Gospels, as discussed by Heldman 1972, 103; Balicka-Witakowska 1991. 


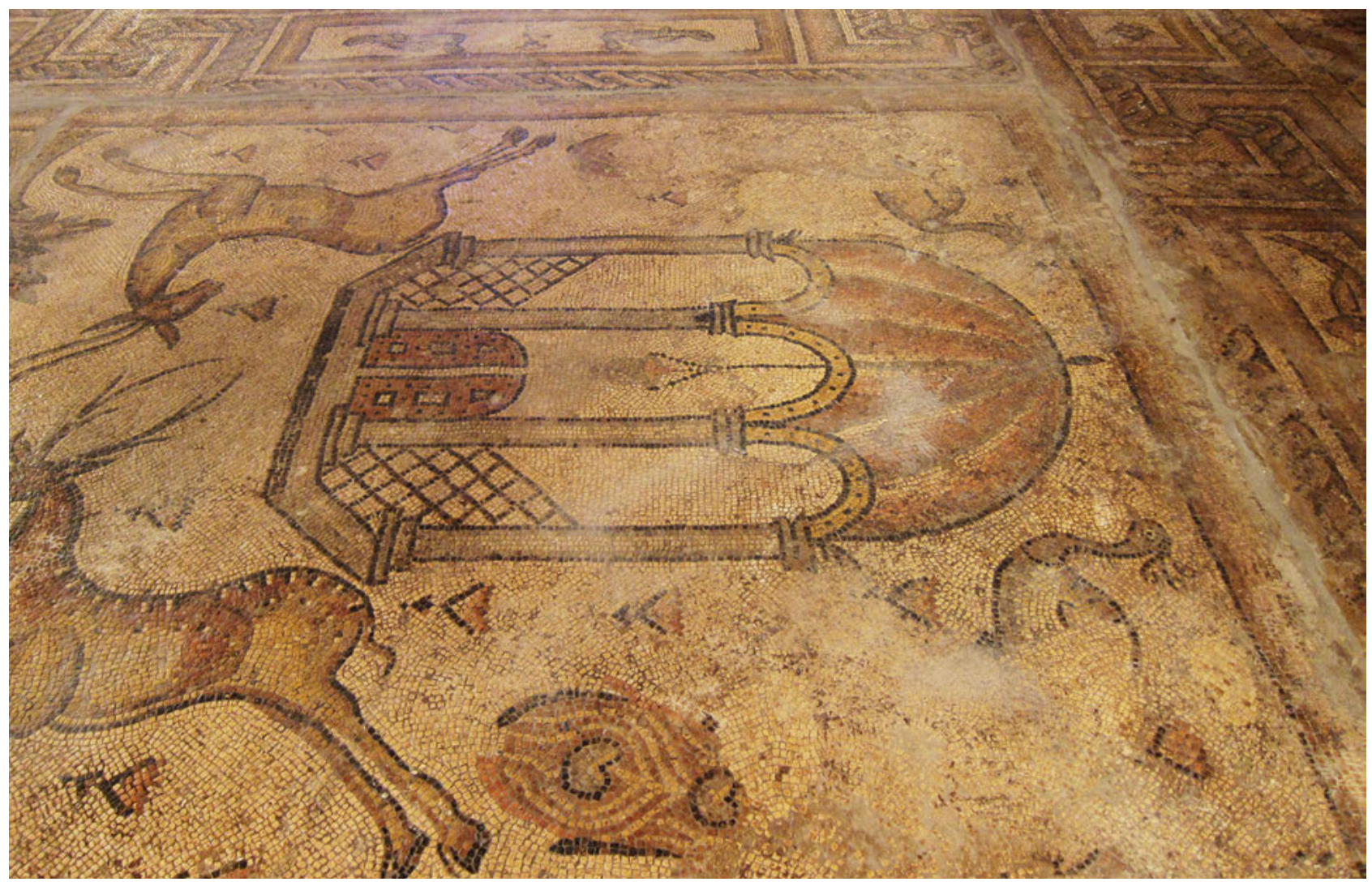

Fig. 12: Tempietto, Syria, Church of Temanaa. ( $)$ Sean Leatherbury, courtesy of the Manar al-Athar project.

Temanaa in Syria (Fig. 12), ${ }^{130}$ attest to the wide circulation of such motifs in Late Antiquity. Likewise, the two deer in the Soissons Gospels and the antelopes in the Temanaa mosaic must also depend on models similar to those which influenced the Ethiopian tradition. This is true for all the animals which surround the Tempietto in Ethiopic gospels, since they recall motifs frequently employed in different media across the larger Mediterranean realm of Late Antiquity. ${ }^{131}$

Taken singularly, these motifs would provide us simply with a terminus post quem for the date of our archetype; for instance, the motif of the peacock with an outspread tail continued to be used in Late Byzantine art, as shown by a Greek manuscript in the Vatican. ${ }^{132}$ Together, however, they have a cumulative effect that forcibly points us towards a late antique date for the archetype from which most early Solomonic miniatures of the Tempietto derive. Clearly, due to the loss of evidence, it cannot be

130 Jouéjati 2012, 244-247, fig. 3; I am grateful to my colleagues Sean Leatherbury and Beatrice Leal for drawing my attention to this mosaic. 131 For an overview of the material and an introduction to their symbolism, see Maguire 1987.

132 Vatican City, Biblioteca Apostolica Vaticana, Vat. gr. 751, fol. 3r. ruled out that the Met's Tempietto, and the miniatures that are related to it, derive from a work displaying late antique iconography that reached Ethiopia after the Aksumite period. Nevertheless, this possibility seems far less likely based on our current understanding of the history of the manuscript tradition of Ethiopia. ${ }^{133}$ Moreover, as this study has shown, a Late Antique origin must be proven for every element in the Ethiopian version of the Tempietto, since the possibility of later amendments needs to be always taken into consideration.

\section{Symbolism}

The last point that needs to be discussed is the symbolism of the Met's leaf. Leroy, Lepage and Bausi have rightly ruled out the presence of allusions to baptism in the Ethiopic version of the Tempietto despite Underwood's suggestions to the contrary, ${ }^{134}$ but they have not gone into

133 For a recent overview of the matter with additional references, see Bausi 2018.

134 Underwood 1950, 80; Leroy 1968, 85-87; Lepage 1987, 161-162; Bausi 2004, 54, 56. For this reason Bausi has correctly observed 
detail about what symbolic associations are at play in this image. ${ }^{135}$ In order to discover what significance the Ethiopian illuminators attributed to this image it is necessary to examine some of the captions that accompany it. The most prominent inscription is the one placed inside the tholos which reads 'Arrangement of the Order Concerning how the sayings of the Four Gospels Agree'. ${ }^{136}$ The inscription is absent in AG-I, but appears, with small variants, in DLB and in most early Solomonic miniatures except for IMA and DSS. In some later examples, the inscription is further abbreviated to 'Arrangement of the Order'. ${ }^{137}$

The consistent presence of this inscription, which Underwood already recognized as a rough translation from the Greek, ${ }^{138}$ shows that the Tempietto functioned as an explicit to the Letter to Carpianus and as a symbol of the harmony of the Four Gospels. Furthermore, as each of the two trees is identified by a caption as a 'tree of paradise', ${ }^{139}$ the miniature alludes to the eternal life which can be obtained through the gospels. ${ }^{140}$ Because the Ethiopic term for paradise also means garden, the captions express the dual relation of paradise to heaven above and earth below and function in concert with the birds and animals present in the scene. ${ }^{141}$ Thus the miniature displays that rich symbolism characteristic of the liturgy and art of the Ethiopian Church. ${ }^{142}$

that the definition of 'fons vitae' or fountain of life is best avoided when discussing the Ethiopian tradition, though it has continued to appear sporadically in the literature, see Balicka-Witakowska 1997, 18; Fiaccadori 2003, 200.

135 The most detailed remarks on this point are still those in Heldman 1972, 104-109.

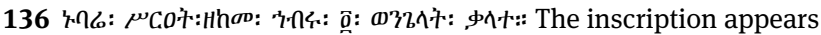
in exactly the same form and position in DMR, which confirms the impression that this manuscript is the closest relative of the Tempietto in the Met leaf.

137 inc: ${ }^{2} \mathrm{CO}$ ' as some scholars have done, see for instance Heldman 1972, 95; Lepage/Mercier 2012, 104.

138 Underwood 1950, 109.

139 The same caption appears also in KTN, DSB, IES-3475, UML. In Ethiopic, the term ( $\delta \dot{d}:)$ is used to designate the wood of the cross. The term used for paradise (72 $7:$ ) in miniatures of the Tempietto is also used in John 19:41 to refer to the garden in which the tomb of Jesus is situated.

140 A common prefatory text found in Ethiopic gospels, the Mäqdəmä wängel, also emphasizes that eternal life is obtained through the word of the four gospels, see Zuurmond 1989, I, 14-16; Cowley 1977, 146-148. The possible relationship between the prefatory texts and the illustrations of Ethiopic gospels has yet to be explored; for the Byzantine tradition, see Galavaris 1979; Nelson 1980; for the Latin, see as examples Walker 1948; Darby 2017.

141 See also Heldman 1972, 106-109; Bausi 2004, 56.

142 Summer 1963, 41-42.
Finally, there is evidence to suggest that the ecclesiastic symbolism which Underwood recognized in the Latin representations of the Tempietto is also at play in the Ethiopic version. In the late thirteenth-century church of Gännäta Maryam, the scene of the Presentation to the Temple features a sanctuary that is represented as a domed structure with curtained columns. This building seems to be a reproduction of the arches of the canon tables and is identified by a caption as Jerusalem. ${ }^{143}$ An almost identical structure, also representing Jerusalem, is purposely placed next to the sanctuary arch in the scene of the Entry into Jerusalem. ${ }^{144}$ This building, like the canon tables and Tempietto, has birds perched at its summit.

The impression that the buildings in Gännäta Maryam were inspired by the decorative features of the Eusebian apparatus is strengthened by a fifteenth-century painted flabellum which also features a representation of the Entry into Jerusalem (Fig. 13). In this example, Jesus advances towards a four-columned tholos that has the same architectural features seen in the illustrated gospels. Significantly, the inscription above the building is the abbreviated caption, 'Arrangement of the Order', that appears in miniatures of the Tempietto. ${ }^{145}$

The ecclesiastical symbolism of the Tempietto in the Ethiopian tradition comes most evidently into play in a miniature of the Annunciation to Zechariah from a fifteenth century Octateuch kept in the church of Gəšän Maryam. ${ }^{146}$ The miniature, known to Leroy through a later copy ${ }^{147}$ is placed just after the canon tables. It shows Zechariah holding a cross and censer while standing in front of a tholos structure. ${ }^{148}$ Evidently, also in this context, the tholos is used not just to mark the ending of the Eusebian apparatus, but also as a representation of the sanctuary of the Temple in Jerusalem in which the Annunciation to Zechariah took place.

143 On this church and its dating, see Heldman/Getachew Haile 1987. The shape of Jerusalem in these two paintings is close to the architectural frames visible in Paris, Bibliothèque nationale de France, syr. 341, fols 212r and 281v.

144 Heldman 1975.

145 For a reproduction and discussion, see Balicka-Witakowska 2004, 28-29, fig. 27.

146 Opinions on the dating of this manuscripts range from the turn to the middle of the fifteenth century; for an overview of its features, see Heldman 1993a, 177-178, cat. 67.

147 For a discussion and reproduction, see Leroy 1962, 196-197, fig. 18. 148 Already in the Rabbula Gospels, f. 3v, the Annunciation to Zachariah takes place in a sanctuary. However, the closest parallel to the Ethiopian miniature are found in Greek and Latin manuscripts, such as British Library, Harley MS 2788, fol. 109r, in which the Annunciation takes places in front of a rotunda, and Biblioteca Apostolica Vaticana, gr. 1613, fol. 31r. 


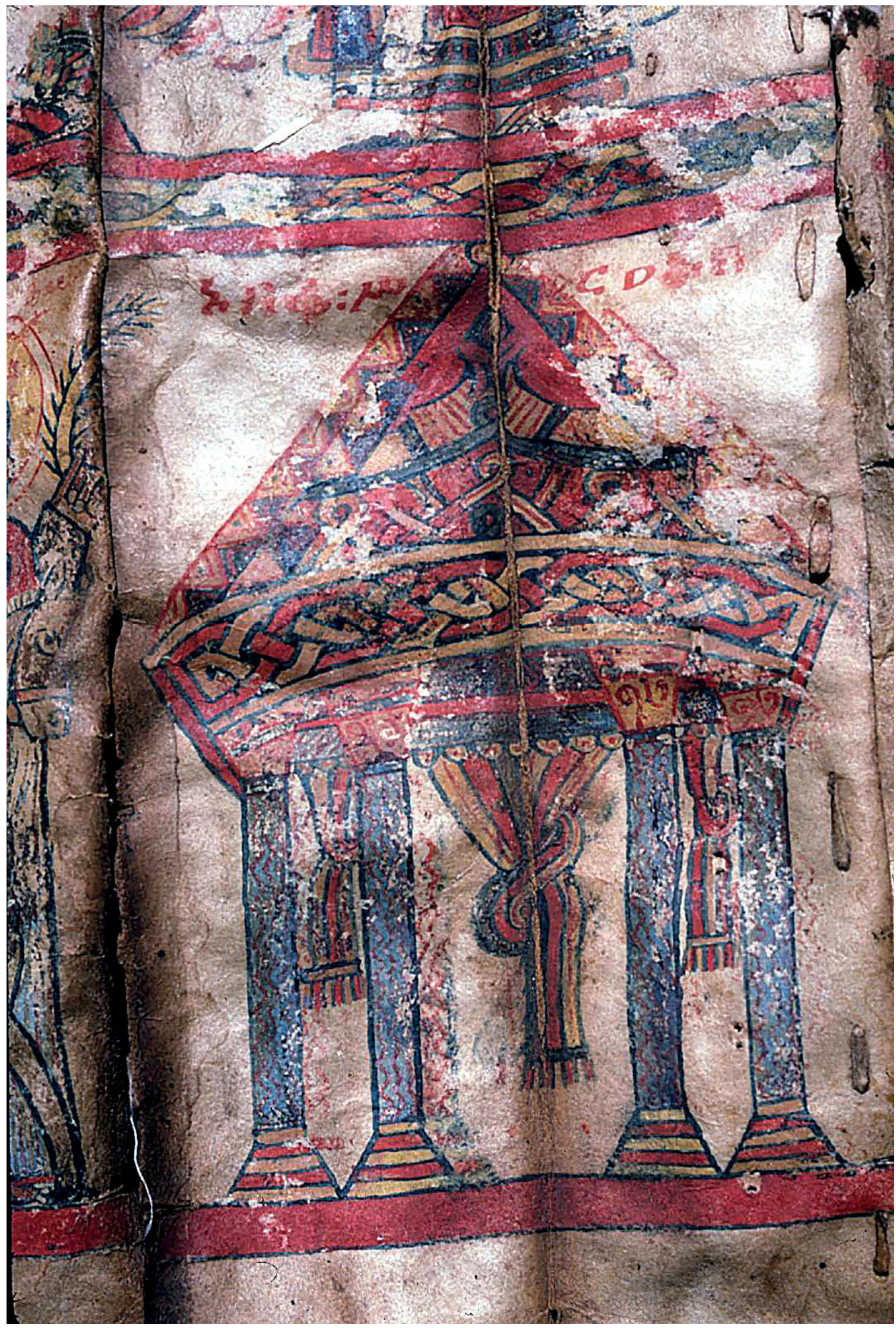

Fig. 13: Flabellum, Entry into Jerusalem (detail), Inda Abbate Wäldä Yoḥannəs. @ Michael Gervers, courtesy of the DEEDS project. 
While it is beyond the aims of this paper to explore the complex shades of meaning associated with the Temple of Jerusalem in Ethiopic literature, it is worth recalling that the Ethiopian Church maintains that it possesses the Ark of the Covenant in the Church of Mary of Zion in Aksum and that a replica of the ark is required for a sanctuary to be consecrated. ${ }^{149}$ Aksum is the new Jerusalem and consequently depictions of it in Ethiopian painting would have had the capacity to evoke both cities to the mind of the Ethiopian artist who painted these miniatures. ${ }^{150}$

\section{Conclusions}

To sum up, this study has shown that the Ethiopian miniature of the Tempietto in the Metropolitan Museum of Art is closely related to a number of other versions of this subject found in Ethiopic gospel books of the fourteenth and early fifteenth centuries. A study of these relatives suggests that the majority of miniatures in this group reflect a common model in different degrees and derive from an archetype which featured an eight-columned tholos with a grille.

The difficulty in reconstructing the features and evolution of the archetype has been highlighted, but it has been argued that it could have reached Ethiopia in the general period of the two Garima Gospels. This conclusion resonates with Zuurmond's belief that there could be multiple translations at the root of the Ethiopic version of the gospels. ${ }^{151}$ An analysis of the surviving examples of the Tempietto in Ethiopic manuscripts also provides some insight into the working methods of Ethiopian illuminators who, it has been shown, sometimes misunderstood the features of their models and sometimes drew, like Ethiopian scribes, from multiple sources.

Research on the elements present in the Met's leaf can help improve our fragmentary understanding of the evolution of Ethiopian art from the Aksumite to the Solomonic period. It also provides evidence on other features of illuminated Ethiopic manuscripts, such as the much-debated origin of the haräg. In the future, the publication of a critical edition of the Ethiopian canon tables may further improve our knowledge of the development of the motif of the Tempietto in illuminated Ethiopic gospels. Indeed, as Nees has put it, illuminated manuscripts 'can only be properly understood when taken as a whole'. ${ }^{152}$ Yet, in the case of Ethiopian art, in order to achieve the kind of synthesis advocated by Nees, the single components of each manuscript need to be first analysed individually. ${ }^{153}$ Clearly, this is a lengthy task and this study only takes a small, albeit necessary, step in the direction of improving our understanding of the manuscript culture of Ethiopia. ${ }^{154}$ Further research is also needed to explain why the Tempietto is attested less frequently and in a more corrupted form, in manuscripts from the mid-fifteenth century onwards and why the motif is no longer employed during the Gondarine period. ${ }^{155}$
149 For an overview, see Heldman 1992; Grierson 1993. It is also worth noting the homily for the cross by Zär'a Ya'zqob in which the whole of Ethiopia is compared to a garden, see Kaplan 2008, 450. 150 Gnisci 2015c, 258-259.
151 Zuurmond 1989, I, 38.

152 Nees 1987, xi; Lowden 1992, 35-39.

153 The importance of cataloguing as a foundation for research on the manuscript culture of Ethiopia has been emphasized by Bausi 2007a.

154 To give a sense of the amount of work that still needs to be carried out it is worth noting that, so far, the only study to adopt the kind of critical method used here for the study of Ethiopian illumination is that of Balicka-Witakowska 1997. Moreover, most of the manuscripts discussed here have yet to be the object of a detailed codicological and textual analysis; these studies are also hindered by the fact that many volumes have not yet been digitized or photographed in full and are kept in hard-to-access monasteries.

155 The Tempietto is also occasionally employed in the decoration of Psalters, see Balicka-Witakowska 1984, 22, fig. 33, pl. 1. 


\section{References}

Amirkhanian, Rouzanna (2008), 'Les tables de canons arméniennes et le thème iconographique de la Jérusalem céleste', Revue des Études Arméniennes, 31, 181-232.

Appleyard, David (1993), Ethiopian Manuscripts, London: Jed Press. Balicka-Witakowska, Ewa (1984), 'Un psautier éthiopien illustré inconnu', Orientalia Suecana, 33-35, 17-48.

Balicka-Witakowska, Ewa (1991), 'L'oiseau dans la cage: exemple éthiopien’, Orientalia Suecana, 40, 53-71.

Balicka-Witakowska, Ewa (1997), La crucifixion sans crucifié dans l'art éthiopien. Recherches sur la survie de l'iconographie chrétienne de l'Antiquité tardive, Bibliotheca nubica et aethiopica, 4, Warsaw: Zaś Pan.

Balicka-Witakowska, Ewa (2004 [2005]), 'The Liturgical Fan and Some Recently Discovered Ethiopian Examples', Rocznik Orientalistyczny, 57/2, 19-46.

Bausi, Alessandro (1994 [1996]), 'Su alcuni manoscritti presso comunità monastiche dell'Eritrea', Rassegna di studi etiopici, 38, 13-69.

Bausi, Alessandro (1997 [1998]), 'Su alcuni manoscritti presso comunità monastiche dell'Eritrea: Parte terza', Rassegna di Studi Etiopici, 41, 13-56.

Bausi, Alessandro (2004), 'Some Short Remarks on the Canon Tables in Ethiopic Manuscripts', in Carmela Baffioni (ed.), Scritti in onore di Clelia Sarnelli Cerqua, Naples: Università degli Studi di Napoli 'L'Orientale', 45-67.

Bausi, Alessandro (2006), 'La Collezione aksumita canonicoliturgica', Adamantius, 12, 43-70.

Bausi, Alessandro (2007a), 'Un indice dell'Evangelo d'oro di Dabra Libānos (Šemazānā, Akkala Guzāy, Eritrea)', Aethiopica, 10: 81-91.

Bausi, Alessandro (2007b), 'La catalogazione come base della ricerca. Il caso dell'Etiopia', in Cenni, Benedetta, Chiara

M. F. Lalli, and Leonardo Magionami (eds), Zenit e Nadir II. I manoscritti dell'area del Mediterraneo: la catalogazione come base della ricerca. Atti del Seminario internazionale. Montepulciano, 6-8 luglio 2007, Medieval Writing, Settimane poliziane di studi superiori sulla cultura scritta in età medievale e moderna, 2, Montepulciano: Thesan\&Turan, 87-108.

Bausi, Alessandro (2014), 'Writing, Copying, Translating: Ethiopia as a Manuscript Culture', in Quenzer, Jörg, Dmitry Bondarev, and Jan-Ulrich Sobisch (eds), Manuscript Cultures: Mapping the Field, Studies in Manuscript Cultures, 1, Berlin, New York: De Gruyter, 37-77.

Bausi, Alessandro (2015), 'La versione etiopica della Epistola di Eusebio a Carpiano', in Rafat Zarzeczny (ed.), Aethiopia fortitudo ejus. Studi in onore di Monsignor Osvaldo Raineri in occasione del suo $80^{\circ}$ compleanno, Orientalia Christiana Analecta, 298, Rome: Pontificio Istituto Orientale, 107-135.

Bausi, Alessandro (2016), 'The Accidents of Transmission: On a Surprising Multilingual Manuscript Leaf: With the Edition of the Ethiopic Version of two Constantinian Epistles (CPG no. 8517, Epistula Constantini imperatoris ad ecclesiam Alexandrinam, and CPG nos 2041 = 8519, Lex lata Constantini Augusti de Arii damnatione)', Adamantius, 22, 303-322.
Bausi, Alessandro (2018), 'Translations in Late Antique Ethiopia', in Franco Crevatin (ed.), Egitto crocevia di traduzioni, $\triangle \mathrm{IA} \wedge$ ОГОІ, 1, Trieste: EUT, 69-99.

Bausi, Alessandro, and Alberto Camplani (2016), 'The History of the Episcopate of Alexandria (HEpA): Editio minor of the fragments preserved in the Aksumite Collection and in the Codex Veronensis LX (58)', Adamantius, 22, 249-302.

Benson, Gertrude R. (1931), 'New Light on the Origin of the Utrecht Psalter', The Art Bulletin, 13/1, 13-79.

Bernabò, Massimo (ed.) (2008), Il Tetravangelo di Rabbula. Firenze, Biblioteca Medicea Laurenziana, Plut. 1.56. L'illustrazione del Nuovo Testamento nella Siria del VI secolo, Rome: Edizioni di Storia e Letteratura.

Bernabò, Massimo (2014), 'The Miniatures in the Rabbula Gospels: Postscripta to a Recent Book', Dumbarton Oaks Papers, 68, 343-358.

Bernabò, Massimo (2017a), 'Nascita di una disciplina. Weitzmann, Toesca, Salmi: la strada si biforca', Rivista di storia della Miniatura, 21, 162-176.

Bernabò, Massimo (2017b) 'Miniatures and Ornament in the Fondo Grünwald', in Vincenzo Ruggieri (ed.) The Syriac Manuscripts of Tur 'Abdin in the Fondo Grünwald, Rome: Orientalia Christiana, 249-370.

Bernabò, Massimo and Grigory Kessel (2016), 'A Syriac Four Gospel Book in Diyarbakır', Convivium, 3/1, 172-203.

Bisconti, Fabrizio (2011), Le pitture delle catacombe romane: restauri e interpretazioni, Todi: Tau.

Blake, Robert P., and Sirarpie Der Nersessian (1942), 'The Gospels of Bert'ay: An Old-Georgian Ms. of the Tenth Century', 16, 226-285.

Bogdanovic, Jelena (2017), The Framing of Sacred Space: The Canopy and the Byzantine Church, Oxford University Press.

Bolman, Elizabeth S. (2006), 'Late Antique Aesthetics, Chromophobia and the Red Monastery, Sohag, Egypt', Eastern Christian Art, 3, 1-24.

Bolman, Elizabeth S. (2016), The Red Monastery Church: Beauty and Asceticism in Upper Egypt, New Haven, CT: Yale University Press.

Bosc-Tiessé, Claire (2010), 'Sainteté et intervention royale au monastère Saint-Étienne de Ḥayq au tournant du XIIle et du XIVe siècle: L'image de lyasus Mo'a dans son Évangile', Oriens Christianus, 94, 199-227.

Bosc-Tiessé, Claire (2008), Les îles de la mémoire. Fabrique des images et écriture de l'histoire dans les églises du lac Tānā, Éthiopie, XVIle-XVIIle siècle, Histoire ancienne et médiévale, 97, Paris: Publications de la Sorbonne.

Boyd, Susan A. and Marlia M. Mango (eds) (1992), Ecclesiastical Silver Plate in Sixth-century Byzantium: Papers of the Symposium Held May 16-18, 1986, at The Walters Art Gallery, Baltimore, and Dumbarton Oaks, Washington, D.C., Washington, DC: Dumbarton Oaks Research Library and Collection.

Branham, Joan R. (1992), 'Sacred Space under Erasure in Ancient Synagogues and Early Churches', The Art Bulletin, 74/3, 375-394.

Brown, Michelle P. (1996), The Book of Cerne: Prayer, Patronage, and Power in Ninth-century England, University of Toronto Press. Buxton, David (1970), The Abyssinians, Washington, DC: Praeger. 
Cecchelli, Carlo, Giuseppe Furlani, and Mario Salmi (1959), The Rabbula Gospels, Facsimile Edition of the Miniatures of the Syriac Manuscript Plut. I, 56 in the Medicaean-Laurentian Library / Evangeliarii Syriaci, Vulgo Rabbulae, in Bibliotheca Medicea-Laurentiana (Plut. I, 56) Adservati Ornamenta. Edenda Notisque Instruenda, Olten and Lausanne: Urs Graf-Verlag.

Chojnacki, Stanislaw (1976), 'The Four Living Creatures of the Apocalypse and the Imagery of the Ascension in Ethiopia', Bulletin de la Société d'archéologie Copte, 23, 159-181.

Chojnacki, Stanislaw (1983), Major Themes in Ethiopian Painting: Indigenous Developments, the Influence of Foreign Models, and their Adaptation from the 13th to the 19th century, Äthiopistische Forschungen, 10, Wiesbaden: Franz Steiner Verlag GMBH.

Chojnacki, Stanislaw (1993), 'The Theme of the Bitter Water in Ethiopian Painting', in Paul B. Henze (ed.), Aspects of Ethiopian Art from Ancient Axum to the 20th Century, London: The Jed Press, 53-67.

Chojnacki, Stanislaw (2006), Ethiopian Crosses: A Cultural History and Chronology, Milan: Skira.

Conti Rossini, Carlo (1901), 'L'evangelo d'oro di Dabra Libānos', Rendiconti della Reale Accademia dei Lincei, Classe di scienze morali, storiche e filologiche, ser. 5a, 10, 177-219.

Cowley, Roger W. (1977), 'New Testament Introduction in the Andemta Commentary Tradition', Ostkirchliche Studien, 26, 144-192.

Crawford, Matthew R. (2015), 'Ammonius of Alexandria, Eusebius of Caesarea and the Origins of Gospels Scholarship', New Testament Studies, 61/1, 1-29.

D’Aiuto, Francesco (2005), 'll libro dei Vangeli fra Bisanzio e l'Oriente: Riflessioni per l'età mediobizantina', in Paolo Cherubini (ed.) Forme e modelli della tradizione manoscritta della Bibbia, Città del Vaticano: Scuola Vaticana di Paleografia, Diplomatica e Archivistica, 309-345.

Dalton, Ormonde M. (1909), Catalogue of the Ivory Carvings of the Christian Era with Examples of Mohammedan Art and Carvings in Bone in the Department of British and Mediaeval Antiquities and Ethnography of the British Museum, London: Trustees of the British Museum.

Darby, Peter (2017), 'The Codex Amiatinus Maiestas Domini and the Gospel Prefaces of Jerome', Speculum, 92/2, 343-371.

Davies, Donald M. (1987), 'The Dating of Ethiopic Manuscripts', Journal of Near Eastern Studies, 46/4, 287-307.

Demus, Otto (1970), Byzantine Art and the West, New York: New York University Pres.

Derat, Marie-Laure (2003), Le domaine des rois éthiopiens, 1270-1527, Espace, pouvoir et monachisme, Histoire ancienne et médiévale, 72, Paris: Publications de la Sorbonne.

Derat, Marie-Laure (2010), 'Les donations du roi Lālibalā: éléments pour une géographie du royaume chrétien d'Éthiopie au tournant du XIle et du XIIle siècle', Annales d'Éthiopie, 25, 19-42.

Dolezal, Marie-Laure (1996), 'The Elusive Quest for the "Real Thing”: The Chicago Lectionary Project Thirty Years on', Gesta, 35/2, 128-141.

Dolezal, Marie-Laure (1998), 'Manuscript studies in the twentieth century: Kurt Weitzmann reconsidered', Byzantine and Modern Greek Studies, 22, 216-263.
Dunbabin, Katherine M.D. (1978), The Mosaics of Roman North Africa: Studies in Iconography and Patronage, Oxford: Clarendon Press.

Ernst, Allie M. (2009), Martha from the Margins: The Authority of Martha in Early Christian Tradition, Leiden, Boston: Brill.

Evans, Helen C. (2006), 'Double-Sided Gospel Leaf', [Recent Acquisitions, A Selection: 2005-2006] The Metropolitan Museum of Art Bulletin, 64/2, 19.

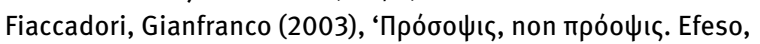
Gerusalemme, Aquileia (Nota a IEph 495, 1 s.)', La Parola del Passato, 58, 182-249.

Fletcher, Aarcadia (ed.) (2005), Art of Ethiopia, London: Paul Holberton.

Flood, Finbarr B. (2012), 'The Qur’an', in Helen C. Evans and Brandie Ratliff (eds), Byzantium and Islam: Age of Transition, 7th-9th Century, New Haven, CT, London: Metropolitan Museum of Art, 265-69.

Frantz, Mary A. (1934), 'Byzantine Illuminated Ornament: A study in Chronology', The Art Bulletin, 16/1, 43-101.

Fritsch, Emmanuel, and Michael Gervers (2012), 'Pastophoria and Altars: Interaction in Ethiopian Liturgy and Church Architecture', Aethiopica, 10/1, 7-51.

Galavaris, George (1979), The Illustrations of the Prefaces in Byzantine Gospels, Byzantina Vindobonensia, 11, Vienna: Verlag der Österreichischen Akademie der Wissenschaften.

Gervers, Michael (2013), 'Finding the Ewosțateans', in Denis Nosnitsin (ed.), Ecclesiastic Landscape of North Ethiopia: Proceedings of the International Workshop, Ecclesiastic Landscape of North Ethiopia: History, Change and Cultural Heritage. Hamburg, July 15-16, 2011, Supplement to Aethiopica, 2, Wiesbaden: Harrassowitz Verlag, 49-60.

Getatchew Haile (2017), 'The Marginal Notes in the Abba Gärima Gospels', Aethiopica, 19, 7-26.

Getatchew Haile (1993), A Catalogue of Ethiopian manuscripts microfilmed for the Ethiopian Manuscript Microfilm Library, Addis Ababa, and for the Hill Monastic Manuscript Library, Collegeville, X: Project Numbers 4001-5000, Collegeville, MN: Hill Monastic Manuscript Library.

Getatchew Haile, and William F. Macomber (1981), A Catalogue of Ethiopian Manuscripts Microfilmed for the Ethiopian Manuscript Microfilm Library, Addis Ababa, and for the Hill Monastic Manuscript Library, Collegeville, V: Project Numbers 1501-2000, Collegeville, MN: Hill Monastic Manuscript Library.

Gnisci, Jacopo (2014), 'The Dead Christ on the Cross in Ethiopian Art: Notes on the Iconography of the Crucifixion in Twelfthto Fifteenth-Century Ethiopia', Studies in Iconography, 35, 187-288.

Gnisci, Jacopo (2015a), 'Picturing the liturgy: Notes on the iconography of the Holy Women at the Tomb in fourteenth- and early fifteenth-century Ethiopian manuscript illumination', Bulletin of the School of Oriental and African Studies, 78/3, 557-595.

Gnisci, Jacopo (2015b), 'The Liturgical Character of Ethiopian Gospel Illumination of the Early Solomonic Period: A Brief Note on the Iconography of the Washing of the Feet', in Rafał Zarzeczny (ed.), Aethiopia fortitudo ejus: Studi in onore di Monsignor Osvaldo Raineri in occasione del suo $80^{\circ}$ compleanno, Orientalia Christiana Analecta, 298, Rome: Pontificio Istituto Orientale, 253-275. 
Gnisci, Jacopo (2015c), 'Shrouding the Divine: Observations on the Iconography of the Entombment of Christ in Ethiopian Illumination of the Fourteenth and Early Fifteenth Centuries', Orientalia Christiana Periodica, 81/2, 473-492.

Gnisci, Jacopo (2017), 'Towards a Comparative Framework for Research on the Long Cycle in Ethiopic Gospels: Some Preliminary Observations', Aethiopica, 20, 70-105.

Gnisci, Jacopo (2018), 'Illuminated Leaves from an Ethiopic Gospel Book in the Newark Museum and in the Walters Art Museum', Manuscript Studies, 3/2, 357-382.

Gnisci, Jacopo, and Rafat Zarzeczny (2017), 'They Came with their Troops Following a Star from the East: A Codicological and Iconographic Study of an Illuminated Ethiopic Gospel Book', Orientalia Christiana Periodica, 83/1, 127-189.

Goldschmidt, Adolph (1928), German Illumination, Florence: Pantheon.

Grabar, André (1958), Les Ampoules de Terre Sainte (Monza Bobbio), Paris: Librairie C. Klincksieck.

Grabar, André (1960), 'Recherches sur les sources juives de l'art paléochretien', Cahiers Archéologiques, 11, 41-71.

Grébaut, Sylvain (1931), 'L'âge du ms. éth. $\mathrm{n}^{\circ} 32$ de Paris', Aethiops, 4, 9-11.

Grierson, Roderick (1993), 'Dreaming of Jerusalem', in Roderick Grierson (ed.), African Zion: The Sacred Art of Ethiopia, New Haven, London: Yale University Press, 5-18.

Grigoryan, Gohar (2014), 'The Roots of Tempietto and its Symbolism in Armenian Gospels', Iconographica, 13, 11-24.

Guidi, Ignazio (1888), 'Le traduzioni dei Vangeli in arabo e in etiopico', Atti della Reale Accademia dei Lincei, Classe di scienze morali, storiche e filologiche, 4, 5-37.

Guilmain, Jaques (1965), 'The Forgotten Early Medieval Artist', Art Journal, 25/1, 33-42.

Hachlili, Rachel (1976), 'The Niche and the Ark in Ancient Synagogues', Bulletin of the American Schools of Oriental Research, 223, 43-53.

Hackspill, L. (1896), 'Die äthiopische Evangelienübersetzung (Math. I-X)', Zeitschrift für Assyriologie und verwandte Gebiete, 11, 117-196, 367-388.

Hammerschmidt, Ernst (1973), Äthiopische Handschriften vom Tānāsee, I: Reisebericht und Beschreibung der Handschriften in dem Kloster des Heiligen Gabriel auf der Insel Kebrān, Verzeichnis der orientalischen Handschriften in Deutschland, 20/1, Wiesbaden: Franz Steiner Verlag GMBH.

Heldman, Marilyn E. (1972), Miniatures of the Gospels of Princess Zir Gānēlā, an Ethiopic Manuscript Dated A.D. 1400/01 (Unpublished PhD Thesis), Saint Luis, Missouri: Washington University.

Heldman, Marilyn E. (1975), 'Christ's Entry into Jerusalem in Ethiopia', in Marcus, Harold G., and John Hinnant (eds), Proceedings of the First United States Conference on Ethiopian Studies, Michigan State University, 2-5 May 1973, East Lansing, MI: African Studies Center, Michigan State University, 43-60.

Heldman, Marilyn E. (1979a), 'An Early Gospel Frontispiece in Ethiopia', Konsthistorisk Tidskrift, 48, 107-121.

Heldman, Marilyn E. (1979b), 'The Kibran Gospels: Ethiopia and

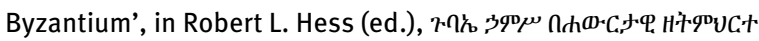
h.tP.s.P Proceedings of the Fifth International Conference on Ethiopian Studies. Session B. April 13-16, 1978. Chicago, USA, Chicago: Office of Publications Services, University of Illinois at Chicago Circle, 359-372.
Heldman, Marilyn E. (1992), 'Architectural Symbolism, Sacred Geography and the Ethiopian Church', Journal of Religion in Africa, 22/3, 222-241.

Heldman, Marilyn E. (1993a), 'The Heritage of Late Antiquity', in Roderick Grierson (ed.), African Zion: The Sacred Art of Ethiopia, New Haven, London: Yale University Press, 117-132.

Heldman, Marilyn E. (1993b), 'The Early Solomonic Period: 1270-1527', in Roderick Grierson (ed.), African Zion: The Sacred Art of Ethiopia, New Haven, London: Yale University Press, 141-192.

Heldman, Marilyn E. (2003), 'Canon tables', in Siegbert Uhlig et al. (eds), Encyclopaedia Aethiopica, I, Wiesbaden: Harrassowitz Verlag, 680-681.

Heldman, Marilyn E., and Monica S. Devens (2009), 'The Four Gospels of Däbrä Mä'ar: Colophon and Note of Donation', in Denis Nosnitsin (ed.), Varia Aethiopica: In Memory of Sevir B. Chernetsov (1943-2005), Scrinium: Revue de patrologie, d'hagiographie critique et d'histoire ecclésiastique, Piscataway, NJ: Gorgias Press.

Heldman, Marilyn E., and Getachew Haile (1987), 'Who is Who in Ethiopia's Past, Part III: Founders of Ethiopia's Solomonic Dynasty', Northeast African Studies, 9/1, 1-11.

Henderson, George (1987), From Durrow to Kells: The Insular Gospel-books, 650-800, London: Thames and Hudson.

Henze, Paul B. (2007), 'Church and monastery treasures of Tigray (private)', in Walter Raunig and Asfa-Wossen Asserate (eds), Orbis Aethiopicus: Ethiopian Art - a Unique Cultural Heritage and Modern Challenge, Bibliotheca nubica et aethiopica, 10, Lublin: Maria Curie-Skłodowska University Press, 150-159.

Iacobini, Antonio, and Lidia Perria (1998), Il Vangelo di Dionisio: Un manoscritto bizantino da Costantinopoli a Messina, Million, 4, Rome: Àrgos.

Jope, Edward M. (2000), Early Celtic Art in the British Isles, Oxford: Clarendon Press.

Juel-Jensen, Bent, and Geoffrey Rowell (eds) (1975), Rock-hewn churches of eastern Tigray: an account of the Oxford University Expedition to Ethiopia, 1974, Oxford: Oxford University Exploration Club.

Kaplan, Steven (2008), 'Finding the True Cross: The Social-Political Dimensions of the Ethiopian Mäsqäl Festival', Journal of Religion in Africa, 38/4, 447-465.

Kessler, Herbert L. (2016), 'The Christianity of Carolingian Classicism', Convivium, 3/1, 22-39.

Klauser, Theodor (1961), 'Das Ciborium in der älteren christlichen Buchmalerei', Nachrichten der Akademie der Wissenschaften in Göttingen: Philologisch-historische Klasse, 7, 191-207.

Klemm, Elisabeth (1972), 'Die Kanontafeln der armenischen Handschrift Cod. 697 im Wiener Mechitaristenkloster’, Zeitschrift für Kunstgeschichte, 35/1, 69-99.

Koehler, Wilhelm (1958), Die karolingischen Miniaturen, II: Die Hofschule Karls des Großen, Berlin: Deutschen Vereins für Kunstwissenschaft.

Kollwitz, Johannes, and Helga Herdejürgen (1979), Die ravennatischen Sarkophage, Die antiken Sarkophagreliefs, 8, Berlin: Gebr. Mann.

Krautheimer, Richard (1942), 'The Carolingian Revival of Early Christian Architecture', The Art Bulletin, 24/1, 1-38. 
Lepage, Claude (1972), 'L’art chrétien d’Éthiopie du Xe au XVe siècle: Premier bilan des missions de 1971 et 1972', Comptes rendus des séances de l'Académie des Inscriptions et Belles-Lettres, $116 / 3,495-514$.

Lepage, Claude (1977a), 'Histoire de l'ancienne peinture éthiopienne (Xe-XVe siècle): Résultats des missions de 1971 à 1977’, Comptes rendus des séances de l'Académie des Inscriptions et Belles-Lettres, 121/2, 325-376.

Lepage, Claude (1977b), 'Esquisse d'une histoire de l'ancienne peinture éthiopienne du xe au xve siècle', Abbay, 8, 59-91.

Lepage, Claude (1987), 'Reconstitution d'un cycle protobyzantin à partir des miniatures de deux manuscrits éthiopiens du XIVe siècle', Cahiers archéologiques, 35, 159-196.

Lepage, Claude (1988), 'Prototypes des deux Tetraevangiles du XIVe siecle a cycle court de trois miniatures', in Anatoly A. Gromyko (ed.), Proceedings of the Ninth International Congress of Ethiopian Studies: Moscow, 26-29 August 1986, VI, Moscow: Nauka, 118-127.

Lepage, Claude (1990), 'Contribution de l'ancien art chrétien d'Éthiopie à la connaissance des autres arts chrétiens', Comptes rendus des séances de l'Académie des Inscriptions et Belles-Lettres, 134/4, 799-822.

Lepage, Claude (1999), 'Les peintures murales de l'église de Betä Maryam à Lalibäla, Éthiopie (rapport préliminaire)', Comptes rendus des séances de l'Académie des Inscriptions et BellesLettres, 143/3, 901-967.

Lepage, Claude (2002), 'À propos d'une image inspirée d'Hénoch', Comptes rendus des séances de l'Académie des Inscriptions et Belles-Lettres, 146/1, 363-386.

Lepage, Claude, and Jacques Mercier (2012), 'Un tétraévangile illustré éthiopien à cycle long du XVe siècle - Codicologie et iconographie', Cahiers archéologiques, 54, 99-174.

Lepage, Claude, and Jacques Mercier (2012b), Lalibela, Wonder of Ethiopia: The Monolithic Churches and their Treasures, WhiteThévenot, Jennifer and Jane Degeorges (trs), London: Paul Holberton.

Leroy, Jules (1955), 'Objectifs des recherches sur la peinture religieuse éthiopienne', Annales d'Éthiopie, 1, 127-136.

Leroy, Jules (1957), 'Nouveaux témoins des canons d’Eusèbe illustrés selon la tradition syriaque', Cahiers archéologiques, 9, 117-140.

Leroy, Jules (1960), 'L'évangéliaire éthiopien du couvent d'Abba Garima et ses attaches avec l'ancien art chrétien de Syrie', Comptes rendus des séances de l'Académie des Inscriptions et Belles-Lettres, 104/1, 200-204.

Leroy, Jules (1962), 'Recherches sur la tradition iconographique des Canons d'Eusèbe en Éthiopie', Cahiers archéologiques, 12, 173-204.

Leroy, Jules (1964), Les manuscrits syriaques à peintures conservés dans les bibliothèques d'Europe et d'Orient: contribution à l'étude de l'iconographie des églises de langue syriaque, Institut Français d'Archéologie de Beyrouth, Bibliothèque Archéologique et Historique, 77, Paris: Librairie orientaliste Paul Geuthner, Institut Français d'Archéologie de Beyrouth.

Leroy, Jules (1967), Ethiopian Painting in the Late Middle Ages and During the Gondar Dynasty, Claire Pace (tr.), New York, NY: F. A. Praeger.
Leroy, Jules (1968), 'Un nouvel évangéliaire éthiopien illustré du monastère d'Abba Garima', in André Grabar (ed.), Synthronon: Art et Archéologie de la fin de l'Antiquité et du Moyen Age. Recueil d'études par André Grabar et ungroupe de ses disciples, Paris: C. Klincksieck, 75-87.

Leroy, Jules (1974), Les Manuscrits Coptes et Coptes-arabes illustrés, Institut Français d'Archéologie de Beyrouth, Bibliothèque Archéologique et Historique, 96, Paris: Librairie orientaliste Paul Geuthner.

Leroy, Jules, Stephen Wright, and Otto A. Jäger (1961), Ethiopia: Illuminated Manuscripts, UNESCO World Art Series, 15, Greenwich, CT: New York Graphic Society.

Lowden, John (1988), Illuminated Prophet Books. A Study of Byzantine Manuscripts of the Major and Minor Prophets, The Pennsylvania State University Press.

Lowden, John (1992), The Octateuchs: A Study in Byzantine Manuscript Illustration, Pennsylvania State University Press.

Lowden, John (2002), “The Transmission of "Visual Knowledge" in Byzantium through Illuminated Manuscripts: Approaches and Conjectures', in Catherine Holmes, and Judith Waring (eds), Literacy, Education and Manuscript Transmission in Byzantium and Beyond, Leiden, Boston, Köln: Brill, 59-80.

Lowden, John (2007), 'The Beginnings of Biblical Illustration', in Eva R. Hoffman (ed.), Late Antique and Medieval Art of the Mediterranean World, Oxford: Blackwell, 117-134.

Maguire, Henry (1987), Earth and Ocean: The Terrestrial World in Early Byzantine Art, Monographs on the Fine Arts, 43, University Park, PA and London: Pennsylvania State University Press.

Mâle, Émile (1917), L'art allemand et l'art français du moyen âge, Paris: A. Colin.

Mann, Griffith C. (2001), 'The Role of the Illuminated Manuscript in Ethiopian Culture', in Deborah E. Horowitz (ed.), Ethiopian Art: The Walters Art Museum, Chailey: Third Millennium, 95-120.

McGurk, Patrick (1993), 'The disposition of numbers in Latin Eusebian canon tables', in Roger Gryson (ed.), Philologia Sacra: Biblische und patristische Studien für Hermann J. Frede und Walter Thele zu ihrem siebzigsten Geburtstag, Freiburg: Herder, 242-258.

McKenzie, Judith S., and Francis Watson (2016), The Garima Gospels: Early Illuminated Gospel Books from Ethiopia, Manar al-Athar Monograph, 3, Oxford: Manar al-Athar.

Mercier, Jacques (2000a), 'La peinture éthiopienne à l'époque axoumite et au XVIIle siècle', Comptes rendus des séances de l'Académie des Inscriptions et Belles-Lettres, 144/1, 35-71.

Mercier, Jacques (ed.) (2000b), L'arche éthiopienne: Art chrétien d'Éthiopie, Paris: Paris musées.

Mercier, Jacques (2009), 'Restoration of holy treasures \& installation of a new museum', in Jacques Mercier and Daniel Seifemichael (eds), Ethiopian Church: Treasures \& Faith, Montpellier: Archange Minotaure, 107-125.

Milson, David W. (2006), Art and Architecture of the Synagogue in Late Antique Palestine: In the Shadow of the Church, Ancient Judaism and Early Christianity, 65, Leiden: Brill.

Monneret de Villard, Ugo (1939), 'Note sulle più Antiche Miniature Abissine', Orientalia, NS 8, 1-24.

Monneret de Villard, Ugo (1943), 'La Majestas Domini in Abissinia', Rassegna di Studi Etiopici, 3, 36-45.

Nees, Lawrence (1987), The Gundohinus Gospels, Cambridge, MA: The Mediaeval Academy of America. 
Nelson, Robert S. (1980), The Iconography of Preface and Miniature in the Byzantine Gospel Book, New York: New York University Press.

Nersessian, Vrej N. (1987), Armenian Illuminated Gospel Books, London: British Library.

Nersessian, Vrej N. (2001), Treasures from the Ark: 1700 Years of Armenian Christian Art, London: The British Library.

Netzer, Nancy (1994), Cultural Interplay in the Eighth Century: The Trier Gospels and the Makings of a Scriptorium at Echternach, Cambridge: Cambridge University Press.

Nordenfalk, Carl (1938), Die spätantiken Kanontafeln. Kunstgeschichtliche Studien über die eusebianische Evangelien-Konkordanz in den vier ersten Jahrhunderten ihrer Geschichte, I: Textband; II: Tafelband, Die Bücherornamentik der Spätantike, 1, Göteborg: Oscar Isacsons Boktryckeri.

Nordenfalk, Carl (1963), 'The Apostolic Canon Tables', Gazette des Beaux Arts, 62, 17-34.

Nordenfalk, Carl (1968), 'An Illustrated Diatessaron', The Art Bulletin, 50/2, 119-140.

Nordenfalk, Carl (1979), Bokmålningar från medeltid och renässans i Nationalmusei samlingar: en konstbok från Nationalmuseum, Stockholm: Rabén \& Sjögren.

Nordenfalk, Carl (1982), 'Canon Tables on Papyrus', Dumbarton Oaks Papers, 36, 29-38.

Nordenfalk, Carl (1984), 'The Eusebian CanonTables: Some Textual Problems', The Journal of Theological Studies, NS 35/1, 96-104.

Nosnitsin, Denis (2013), Churches and Monasteries of Tagray: $A$ Survey of Manuscript Collections, Supplement to Aethiopica, 1, Wiesbaden: Harrassowitz Verlag.

Oliver, Harold H. (1959), 'The Epistle of Eusebius to Carpianus: Textual Tradition and Translation', Novum Testamentum, 3/1, 138-145.

Ousterhout, Robert (1990), 'The Temple, the Sepulchre, and the Martyrion of the Savior', Gesta, 29/1, 44-53.

Perczel, Csilla F. (1989), 'Ethiopian Illuminated Ornament', in Proceedings of the First International Conference on the History of Ethiopian Art: Held at the Warburg Institute of the University of London, October 21 and 22, 1986, London: The Pindar Press, 59-62.

Phillipson, David W. (2009), Ancient Churches of Ethiopia: FourthFourteenth Centuries, New Haven: Yale University Press.

Piccirillo, Michele (1993), The Mosaics of Jordan, ed. Patricia M. Bikai and Thomas A. Dailey, American Center of Oriental Research Publications, 1, Amman: American Center of Oriental Research.

Porter, Arthur K. (1931), The Crosses and Culture of Ireland, New Haven and London: Yale University Press.

Raby, Julian, and Sebastian Brock, (2014), 'New Light on Syriac Painting in the Eleventh Century: Re-dating British Library Or. 3327', Eastern Christian Art, 10, 33-80.

Ricci, Lanfranco (1961), 'Ethiopia' in Massimo Pallotino et al. (eds), Encyclopedia of World Art, V, New York: McGraw Hill, 75-100.

Ricci, Lanfranco (1959), 'Qualche osservazione sull'iconografia della «Maiestas Domini»’, Rassegna di Studi Etiopici, 15, 106-111.

Romilly Allen, John (1904), Celtic art in pagan and Christian times, London: Methuen \& Co.

Rosenbaum, Elisabeth (1955), 'The Vine Columns of Old St. Peter's in Carolingian Canon Tables', Journal of the Warburg and Courtauld Institutes, 18/1-2, 1-15.
Rosenthal, Erwin (1967), 'Some Observations on Coptic Influence in Western Early Medieval Manuscripts', in Hellmut LehmannHaupt (ed.), Homage to a Bookman: Essays on Manuscripts, Books and Printing Written for Hans P. Kraus on His 60th Birthday Oct. 12, 1967, Berlin: Gebr. Mann, 51-74.

Rutschowscaya, Marie-Hélène (1990), Tissus Coptes, Paris: Éditions Adam Biro.

Ṣādwā, Pāwlos (1952), 'Un manoscritto etiopico degli Evangeli’, Rassegna di Studi Etiopici, 11, 9-28.

Schapiro, Meyer (1973), 'The Miniatures of the Florence Diatessaron (Laurentian ms Or. 81): Their Place in Late Medieval Art and Supposed Connection with Early Christian and Insular Art', The Art Bulletin, 55/4, 494-531.

Schneider, Madeleine (1970), 'Deux actes de donation en arabe', Annales d'Éthiopie, 8, 79-87.

Semoglou, Athanasios (2009), 'La Transfiguration du Christ, une vision éminente: Représenter Philippe à la place de Jacques à l'église Betä Maryam à Lalibäla en Ethiopie', Eastern Christian Art, 6, 119-126.

Skehan, Patrick W. (1954), 'An Illuminated Gospel Book in Ethiopic', in Dorothy Miner (ed.), Studies in Art and Literature for Belle da Costa Greene, Princeton, NJ: Princeton University Press, 350-357.

St. Clair, Archer (1979), 'The Visit to the Tomb: Narrative and Liturgy on Three Early Christian Pyxides', Gesta, 18/1, 127-135.

Sulzberger, Suzanne (1955), 'Un exemple d'influence copte sur un manuscrit précarolingien (Paris, BNF, lat. 12168)', Scriptorium, 9/2, 263-267.

Summer, Claude (1963), 'The Ethiopic Liturgy: An Analysis', Journal of Ethiopian Studies, 1/1, 40-46.

Taddesse Tamrat (1970), 'The Abbots of Däbrä-Hayq 1248-1535', Journal of Ethiopian Studies, 8/1, 87-117.

Taddesse Tamrat (1972), Church and state in Ethiopia, 1270-1527, Oxford: Clarendon Press.

Taddesse Tamrat (1974), 'Problems of Royal Succession in Fifteenth Century Ethiopia: A Presentation of the Documents', in IV Congresso Internazionale di Studi Etiopici, (Roma, 10-15 aprile 1972), I, Rome: Accademia Nazionale dei Lincei, 501-535.

Toesca, Pietro (1965), Storia dell'arte Italiana, I: Il Medioevo, Turin: Unione Tipografico-Editrice Torinese.

Tribe, Tania C. (1997), 'The Word in the Desert: The Wall-paintings of Debra Maryam Korkor (Ger'alta, Tigray)', in Katsuyoshi Fukui, Eisei Kurimoto, and Masayoshi Shigeta (eds), Ethiopia in Broader Perspective: Papers of the XIIIth International Conference of Ethiopian Studies, Kyoto, 12-17 December 1997, III, Kyoto: Shokado, 35-61.

Uhlig, Siegbert (1988), Äthiopische Paläographie, Äthiopistische Forschungen, 22, Stuttgart: Franz Steiner Verlag.

Uhlig, Siegbert (1984), 'Ornamente und Marginalzeichen in den äthiopischen Handschriften; ein Vergleich mit anderen semitischen und mit koptischen Codices', Bibiliotheca Orientalis, 41, 318-335.

Uhlig, Siegbert (1989), 'Funktion und Bedeutung der Ornamente in Äthiopischen Kodizes', in Proceedings of the First International Conference on the History of Ethiopian Art: Held at the Warburg Institute of the University of London, October 21 and 22, 1986, London: The Pindar Press, 56-59.

Underwood, Paul A. (1950), 'The Fountain of Life in Manuscripts of the Gospels', Dumbarton Oaks Papers, 5, 41-138. 
Veelenturf, Kees (2001), 'Irish High Crosses and Continental Art: Shades of Iconographical Ambiguity', in Colum Hourihane (ed.), From Ireland Coming: Irish Art from the Early Christian to the Late Gothic Period and Its European Context, Princeton: Index of Christian Art in association with Princeton University Press, 83-101.

Velmans, Tania (2017), L'Orient chrétien: Art et croyances, Paris: Picard.

Vieillard, May (1945), 'Les canons d'évangéliaires de la Basse Antiquité', Cahiers Archéologiques, 1, 113-123.

Vikan, Gary (ed.) (1973), Illuminated Greek Manuscripts from American Collections, Princeton, NJ: Princeton University Press.

Walker, Robert M. (1948), 'Illustrations to the Priscillian Prologues in the Gospel Manuscripts of the Carolingian Ada School', The Art Bulletin, 30/1, 1-10.

Weitzmann, Kurt (1933), Die armenische Buchmalerei des 10. und beginnenden 11. Jahrhunderts, Istanbuler Forschungen, 4, Bamberg: J. M. Reindl.

Weitzmann, Kurt (1935), Die byzantinische Buchmalerei des 9. und 10. Jahrhunderts, Berlin: Verlag Gebr. Mann.

Weitzmann, Kurt (1947), Illustrations in Roll and Codex: A Study of the Origin and Method of Text Illustration, Princeton University Studies in Manuscript Illumination, 2, Princeton, New Jersey: Princeton University Press.

Weitzmann, Kurt (1966), 'Various Aspects of Byzantine Influence on the Latin Countries from the Sixth to the Twelfth Century', Dumbarton Oaks Papers, 20, 1-24.

Weitzmann, Kurt (1977), Late Antique and Early Christian Book Illumination, London: Chatto and Windus.

Werner, Martin (1969), 'The Four Evangelist Symbols Page in the Book of Durrow', Gesta, 8/1, 3-17.
Werner, Martin (1972a), 'The Madonna and Child Miniature in the Book of Kells: Part l', The Art Bulletin, 54/1, 1-23.

Werner, Martin (1972b), 'The Madonna and Child Miniature in the Book of Kells, Part II', The Art Bulletin, 54/2, 129-139.

Werner, Martin (1990), 'The Cross-Carpet Page in the Book of Durrow: The Cult of the True Cross, Adomnan, and lona', The Art Bulletin, 72/2, 174-223.

Wilkinson, John (1972), 'The Tomb of Christ: An Outline of its Structural History', Levant, 4/1, 83-97.

Wright, David H. (1979), 'The Canon Tables of the Codex Beneventanus and Related Decoration', Dumbarton Oaks Papers, 33, 135-155.

Zamparo, Laura (2018), 'Le pagine ornamentali del Codex Vindobonensis 847', Studi Medievali, 59/2, 505-21.

Zanotti-Eman, Carla (1992), 'Gli areg nei manoscritti dell'Institute of Ethiopian Studies', in Piotr O. Scholz (ed.), Orbis Aethiopicus: Studia in honorem Stanislaus Chojnacki natali septuagesimo quinto dicata, septuagesimo septimo oblata, I, Bibliotheca nubica, 3, Albstadt: Karl Schuler Publishing, 475-499.

Zanotti-Eman, Carla (1993), 'Linear Decoration in Ethiopian Manuscripts', in Roderick Grierson (ed.), African Zion: The Sacred Art of Ethiopia, New Haven and London: Yale University Press, 63-67.

Zuurmond, Rochus (1989), Novum Testamentum Aethiopice: The Synoptic Gospels. I: General Introduction. II. Edition of the Gospel of Mark, Äthiopistische Forschungen, 27, Stuttgart: Franz Steiner Verlag.

Zuurmond, Rochus, and Curt Niccum (2012), 'The Ethiopic Version of the New Testament', in Bart D. Ehrman, and Michael W. Holmes (eds), The Text of the New Testament in Contemporary Research: Essays on the Status Quaestionis. Second Edition, Leiden: Brill, 231-252. 